\title{
3. \\ Tragedy's Forgotten Beauty: the Medieval Return of Orestes
}

\author{
Francisco Prado-Vilar
}

The father prayed, called to his men to lift her with strength of hand swept in her robes aloft and prone above the altar, as you might lift a goat for sacrifice, with guards against the lips' sweet edge, to check the curse cried on the house of Atreus by force of bit and speech drowned in strength. Pouring then to the ground her saffron mantle she struck the sacrificers with the eyes' arrows of pity, lovely as in a painted scene, and striving to speak.

Aeschylus, Agamemnon 231-43, transl. Lattimore

It is a poignant piece of history that Spanish Romanesque sculpture finds one of its stylistic and emotional foundations in a Greek tragedy. The ancient myth's unexpected point of entry into the historical reality of medieval Iberia materialised in the Castilian church of Santa María de Husillos (Palencia), where a magnificent Roman sarcophagus decorated with episodes of the saga of Orestes was reused in a Christian burial (Figures 3.1,3.2, and 3.3). ${ }^{1}$ For over a century, the sarcophagus had lain silent in the small church, holding the remains of one of those noblemen who, at the dusk of the first millennium, prepared the way for the emergence of the Kingdom of Castile. ${ }^{2}$ Yet, in the spring of 1088 ,

1 Now in the Museo Arqueológico Nacional, Madrid (inv. no. 2839); see García y Bellido 1949, 212-17; and also Fernández-Guerra y Orbe 1872 (written when the sarcophagus was transferred to Madrid) especially for its beautiful lithograph. Dated to the first decades of the $2^{\text {nd }}$ century, the sarcophagus must have found its way into Hispania in antiquity.

2 Since its foundation in the $10^{\text {th }}$ century, Santa María de Husillos was connected to the powerful Ansúrez family - which has led scholars to speculate that the Orestes sarcophagus could have been used for the burial of one its most prominent members, Fernando Ansúrez, count of Monzón. Other leaders of the Kingdom of León received burials in antique sarcophagi during the $10^{\text {th }}$ century, showing how these were valued as status-symbols by the Castilian elite. The famous first independent count of Castile, Fernán González, a rival and 


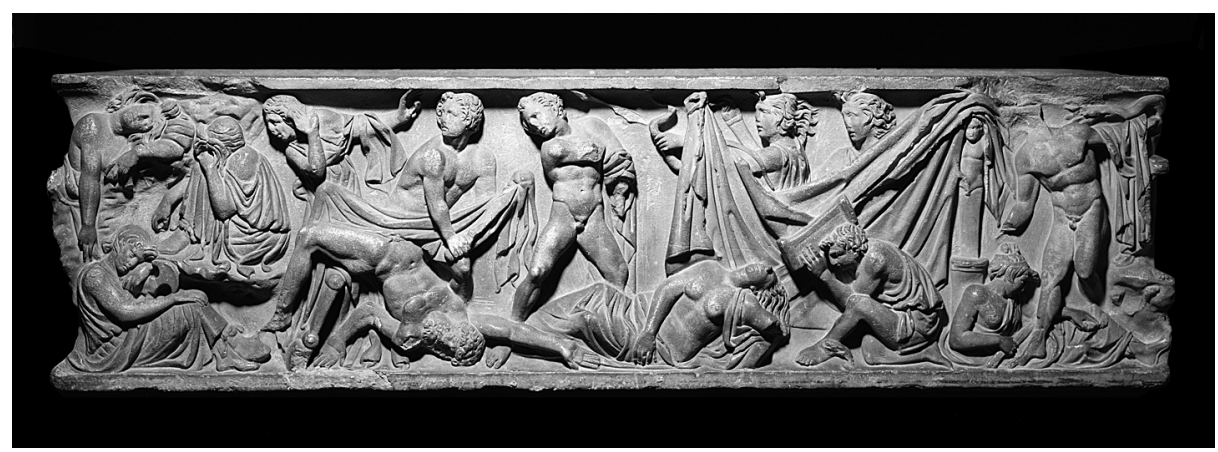

Figure 3.1: Orestes sarcophagus (early second century A.D.). Front: the revenge of Orestes. Madrid, Museo Arqueológico Nacional, inv. 2839. Photograph: courtesy of Museo Arqueológico Nacional.

when King Alfonso VI of León-Castile summoned the bishops and nobles of his realm to meet at Husillos for a momentous council, its imagery of crime, revenge and sacrifice seemed to be speaking, once more, to the present.

Their urgent task was to restore peace and social order after a year of political, military and ecclesiastical unrest that had almost split the kingdom. ${ }^{3}$ During the council, there were disputes punctuated by episodes of high drama almost recalling the tableaux carved on the sarcophagus that stood nearby. One may imagine the Castilian nobles entering the church of Husillos, some for the

contemporary of Fernando Ansúrez, and his wife Sancha were also interred in two antique sarcophagi, originally located in the family monastery of San Pedro de Arlanza and now in the Colegiata de Covarruvias in Burgos (see Moralejo 1984a). The literature on the reutilization of antique sculpture in the Middle Ages is vast but the standard study remains Adhémar 1939. See also Greenhalgh 1989. In his excellent new book on Roman mythological sarcophagi (Zanker and Ewald 2004), P. Zanker includes a chapter on the reuse of examples such as the Hippolytus sarcophagus in Pisa.

3 The magnates of Galicia, led by count Rodrigo Ovéquiz, had revolted against the king, presumably due to his decision to hand over the administration of the region to count Raymond of Burgundy, a nephew of abbot Hugh of Cluny, who had settled at the Leonese court a few years earlier. The early-12 $2^{\text {th }}$-century chronicle known as the Historia Compostellana suggests that the ultimate goal of the rebels, aided by the bishop of Santiago de Compostela, Diego Peláez, was the severance of Galicia from León-Castile and its surrender to William the Conqueror. Anglo-Norman epic sources seem to recall this possible connection between William and the Galician aristocracy signalling that the horse that led him to victory at the Battle of Hastings had been raised in Santiago de Compostela (see Moralejo 1994, 175). However, with the defeat of the rebels, the incredible historical possibility of a Norman takeover of Northwestern Spain was thwarted, bishop Diego Peláez was put in prison by Alfonso VI and later brought in chains before the papal legate at the council of Husillos, where 'the bishop, proclaiming before the council that he was unworthy of the episcopate, surrendered his pastoral ring and staff' (Falque Rey 1988, 15). For the background of these events, see Fletcher 1984, 29-50, Fletcher 1978, 7-10, Reilly 1988, 185-209, and Reilly 1982, 3-43, esp. $14-17$. 


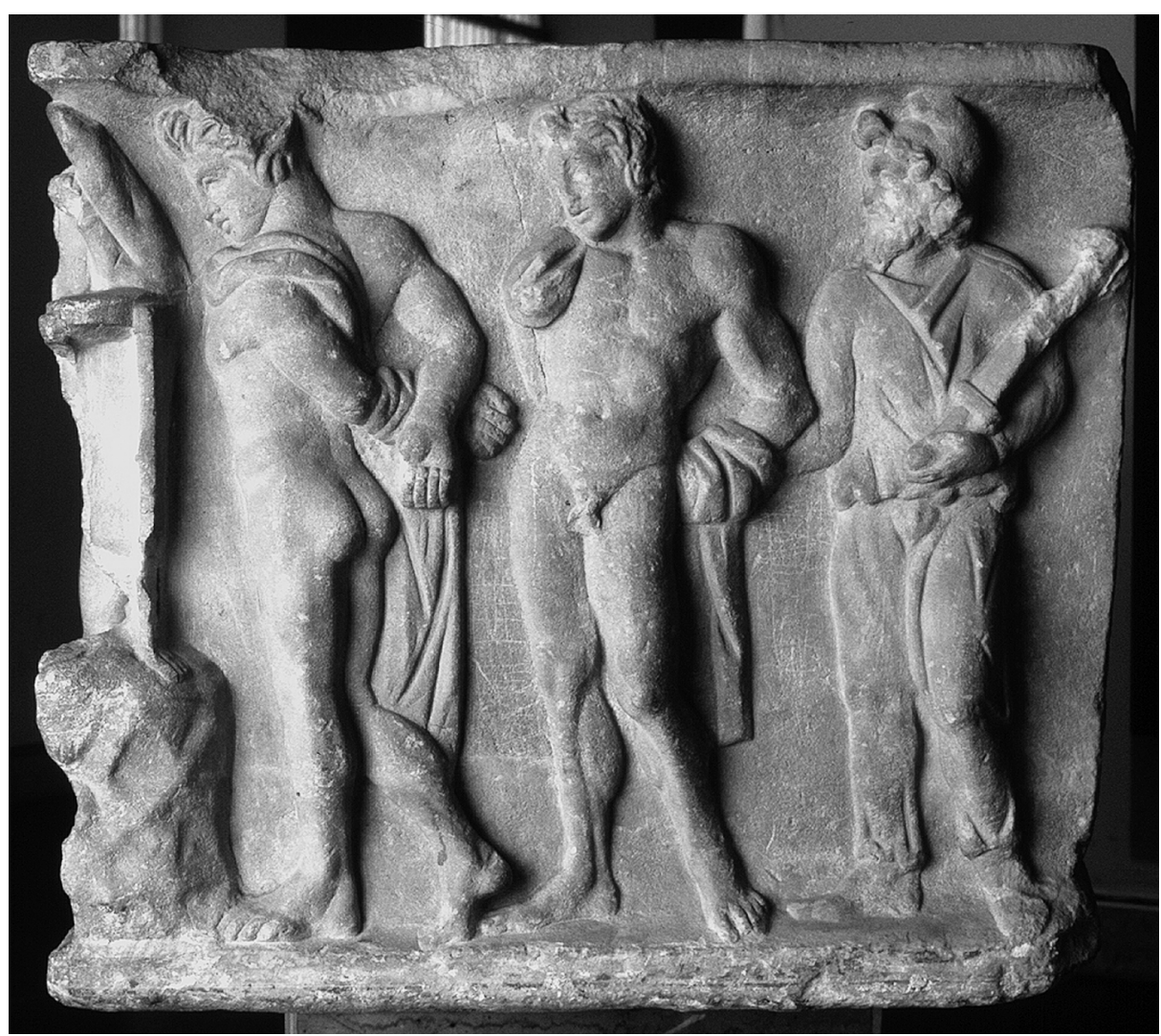

Figure 3.2: Orestes sarcophagus (early second century A.D.). Right side: Orestes and Pylades captured by the tauri. Madrid, Museo Arqueológico Nacional, inv. 2839. Photograph: courtesy of Museo Arqueológico Nacional.

first time, being mesmerised by the beauty and strangeness of the images on the sarcophagus, such as Orestes, naked and with hands tied, led to sacrifice by his captors (Figure 3.2), only later to experience, in the flesh, similarly gripping scenes, such as the detention and disrobing of the bishop of Santiago de Compostela, Diego Peláez, before the papal legate. Art and life might suddenly seem to merge in a series of echoing gestures, as if the ancient myth provided the background and choreography for the unfolding of history.

No document records the impact of the Roman reliefs on those who attended the council (nor on the chronicler of the Historia Compostellana who would recreate in writing, a few decades later, episodes such as Diego Peláez's deposition). ${ }^{4}$ But, it

4 We will probably never know whether the $12^{\text {th }}$-century author of the Historia Compostellana, having visited Husillos sometime in his life, was inspired by the sarcophagus in his literary recreation of the council. Little remains of the building where it happened, or of the building 


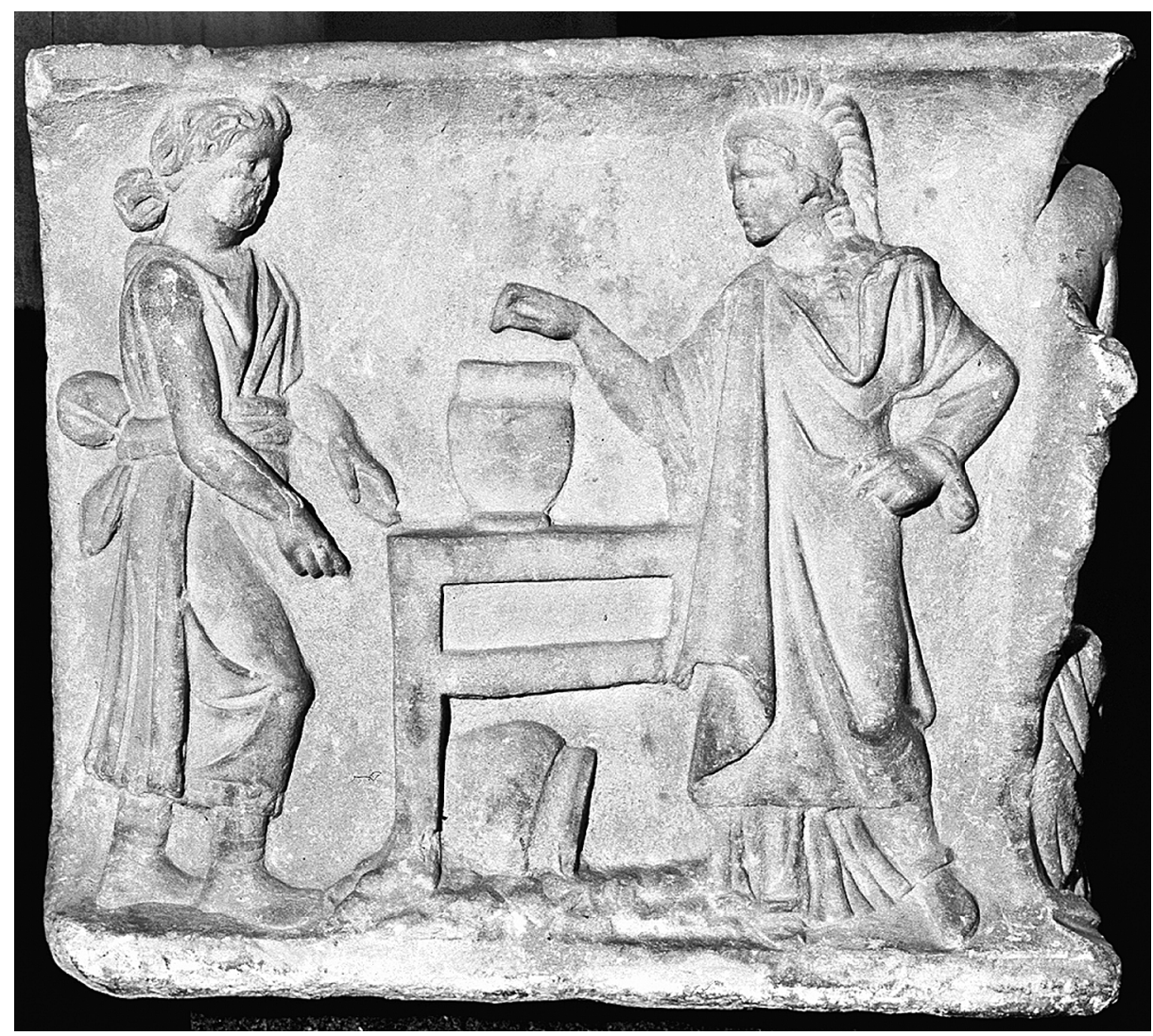

Figure 3.3: Orestes sarcophagus (early second century A.D.). Left side: Athena at the trial of the Areopagus. Madrid, Museo Arqueológico Nacional, inv. 2839. Photograph: courtesy of Museo Arqueológico Nacional.

is hardly a coincidence that soon after that memorable event, which exposed the sarcophagus to a large gathering of potential art patrons, a paraphrase of its frieze was carved on a capital decorating the main apse of the nearby church of San Martín de Frómista (Figure 3.4).5 'Traces of the ancient model,' observed Serafín Moralejo, the scholar who first noticed the striking correspondence between the 'Roman' and the 'Romanesque' works, 'are as intense as the interpretation creative, which suggests that the piece represents the genesis of a style. In the subtle compositional cadences of the sarcophagus frieze, the master

that the author of the Historia Compostellana could have seen in the early $12^{\text {th }}$ century. The church of Husillos was completely rebuilt in the $13^{\text {th }}$ century and drastically renovated several times since, so the sarcophagus is one of the few points of continuity, and the only extant material witness to the council. For the history of Santa María de Husillos, see Hernando Garrido 2002.

5 The capital is now in the Museo Provincial de Palencia (Palencia), inv. no. 227. 


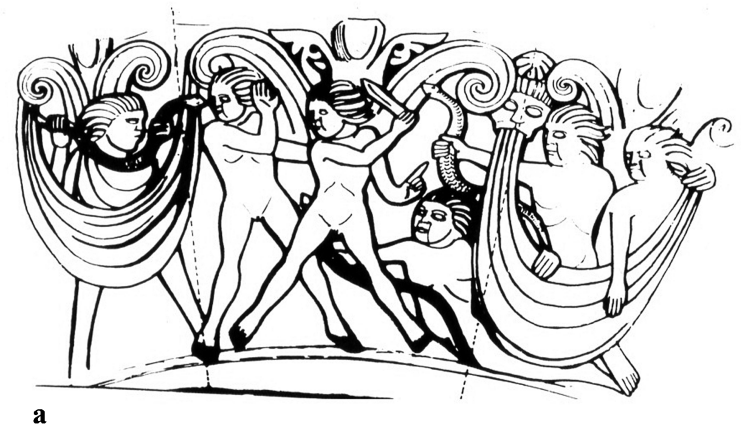

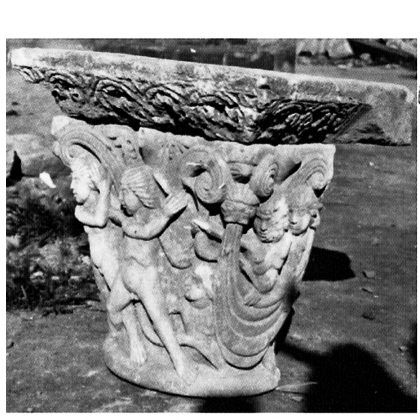

b

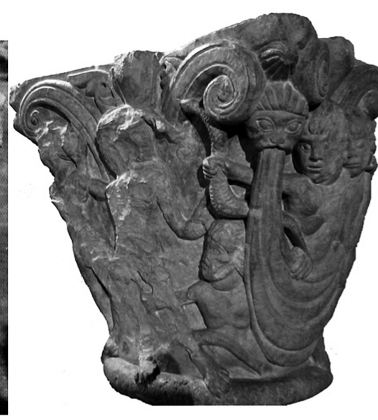

c

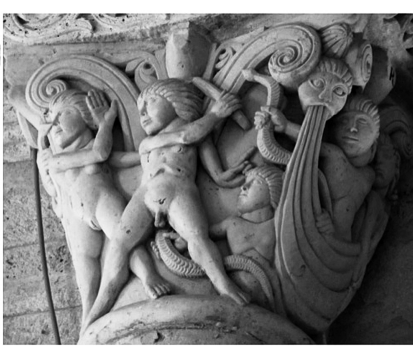

d

Figure 3.4: Capital representing Cain killing Abel from the church of San Martín de Frómista. a. Scheme of the capital by Serafín Moralejo (published by courtesy of Serafín Moralejo). b. Photograph of the capital during restoration ca. 1900. Photograph: courtesy of Fundación Eugenio Fontaneda. c. Capital in its current display at the Museo Arqueológico Provincial de Palencia, inv. 227. Photograph: author. d. Modified modern copy in the central apse of San Martín de Frómista. Photograph: author.

of Frómista discovered rhythmic accents that he used to articulate the plastic architecture of the capital, such as the $\mathrm{x}$-shaped postures of the figures stretched across the fork formed by the volutes, and the ample curves describing the draperies with which he closes and gives balance to the composition of the side faces. ${ }^{6}$ This creative encounter, first described by Moralejo in a paper delivered at the International Congress of the History of Art in Granada in 1973, was just the beginning of an extraordinary artistic watershed that would forge the seminal place of the Orestes sarcophagus from Husillos in the history of medieval art. $^{7}$

Moralejo followed this initial observation with a series of remarkable studies, which pursued this medieval artist's obsession with the classical model, its dissemination in later commissions of the workshop (especially the Cathedral

6 Moralejo 1994b, 211.

7 Moralejo 1976. 
of Jaca), and contribution towards shaping the visual morphology of the socalled 'Hispano-Languedocian' Romanesque style (Figure 3.5). ${ }^{8}$ Moralejo was primarily interested in elucidating the formal genealogy of the style, tracing the lineage of figures from Romanesque monuments back to their classical ancestors in the sarcophagus. He limited his findings to the establishment of a formal aetiology partly because he assumed (reasonably) that medieval viewers would find the subject-matter of the sarcophagus remote and inaccessible, and partly because he had some uncertainty about the iconography of the first link in its Romanesque succession, the Frómista capital.

In this article I shall address those two issues as I explore the subtle permutations of form and iconographic meaning that link the sarcophagus to its Romanesque offspring. I will show how a thematic parallel runs alongside to the formal lineage outlined by Moralejo. By understanding the ways in which these two genealogies - formal and iconographic - evolved in response to the historical, political and psychological conditions of patronage and reception, we may begin to grasp the function of the sarcophagus in larger cultural terms, as a true lieu de mémoire where the artistic memory of Spanish Romanesque sculpture 'crystallizes and secretes itself.' As we will see, like the lieux de mémoire conceptualized in Pierre Nora's historical project, the Husillos sarcophagus is, for the genealogy of the Romanesque, a monument that 'exists because of its capacity for metamorphosis, an endless recycling of its meaning and a unpredictable proliferation of its ramifications. ${ }^{10}$ In the course of this analysis, we will discover two more genealogical ramifications, one historic and the other historiographic, which will allow us to view the sarcophagus as an active witness to history and a nexus that links history (and the present) to the time of myth.

\section{La Beauté Oubliée}

Moralejo's discovery occurred in the realm of memory. He was guided by the recollections of Émile Bertaux who, visiting Frómista in 1905, saw sculptures that reminded him of the beauté oubliée of Roman sarcophagi:

L'artiste ... a étudié des sarcophages antiques, pour y copier des figures entières, qu'il a laissées nues, et qui, dans les formes de leurs corps et dans le sourire de leur

8 See, especially, Moralejo 1979, 1985, and 1987. For the influence of formal elements derived from the sumptuary arts in the definition of the style, see Moralejo 1982. For an overview of Hispano-Languedocian sculpture, see Gaillard 1938, and Durliat 1990.

9 Nora 1989, 7.

10 Ibid.,9. 


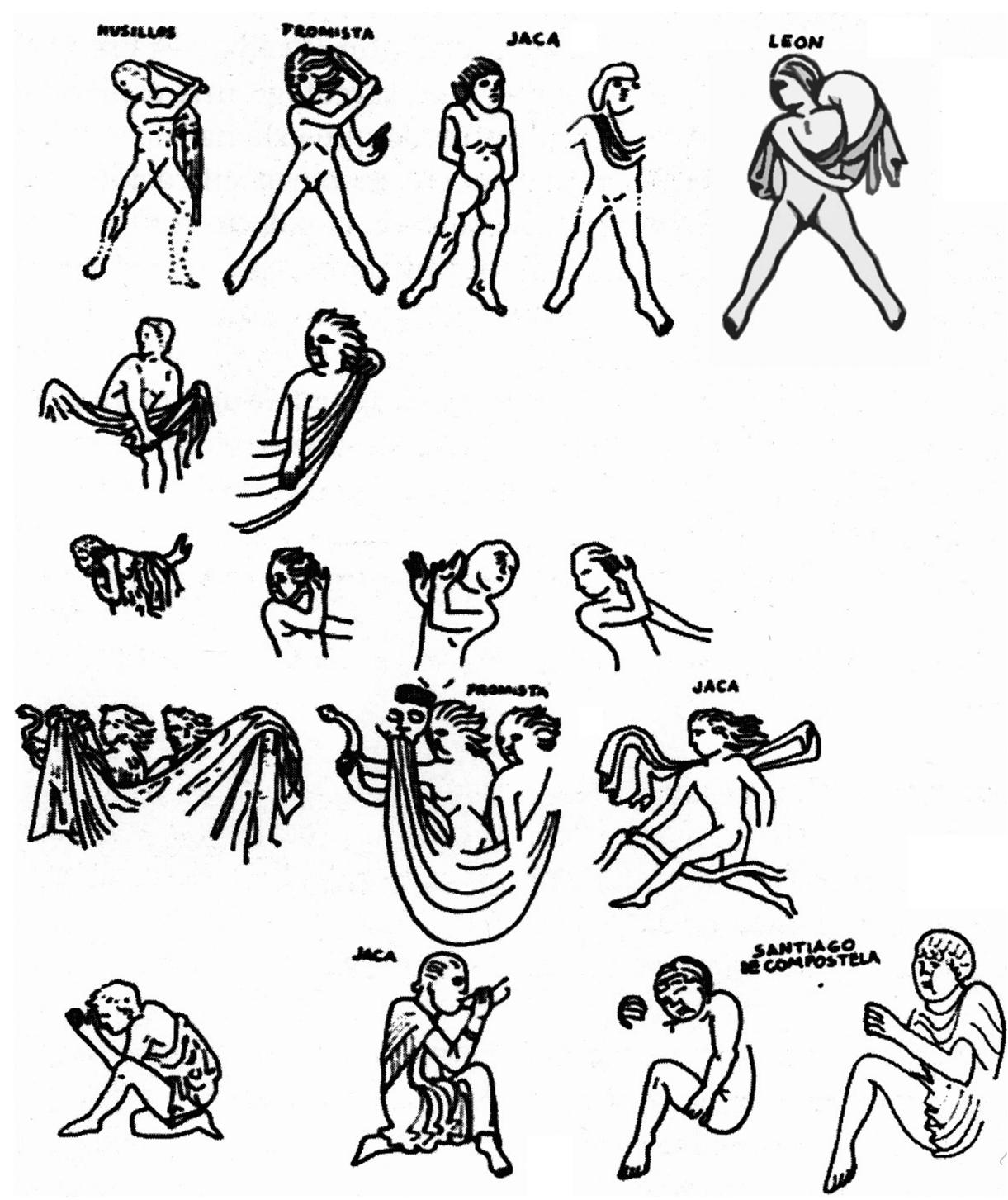

Figure 3.5: Scheme showing the Romanesque descendancy of the figures from the Orestes sarcophagus (by Serafín Moralejo and published with his kind permission).

visage, font apparaitre, au milieu des monstres barbares qu'elles combattent au chevauchent, une vision fugitive de la beauté oubliée. ${ }^{11}$

11 Bertaux 1906, 244. For a brief account of Bertaux's trip to Spain and Portugal, where he spent 'longues semaines, pour relever, étudier, photographier tant monuments remarquables et presque ignores,' see Bertaux 1924, 2-3. 
This observation inspired Moralejo to follow his own memory trail, finally reuniting two works that had once been closely connected in the Middle Ages, but which had been by then removed to museums - the Husillos sarcophagus and the Frómista capital. The same year that Bertaux delighted in catching glimpses of an Apollonian beauty amidst the monstres at Frómista, Aby Warburg, a scholar more sensitive to the Dionysian undercurrent of antiquity, gave a lecture in Hamburg on 'the long migration that brought superlatives of gesture from Athens, by way of Rome, Mantua and Florence, to Nuremberg and into the mind of Albrecht Dürer.' ${ }^{12}$ Expounding on his previous investigations on 'the circulation and exchange of expressive forms in art,' he traced the origins of the composition of Dürer's Death of Orpheus to Greek vase painting via Italian Renaissance art. The figure of the dying Orpheus constituted what he would call a Pathosformel, or pathos formula - the condensed gestural expression of a psychic movement. ${ }^{13}$ Both the primal corporeal expression of an emotional charge and an iconographic formula containing the fundamental kernel of meaning that could be reactivated at any point of encounter with the work in different historical periods, the concept of the Pathosformel became the centre of his project to retrieve an 'historical psychology of the human expression. ${ }^{, 14}$

This project materialised in the picture atlas Mnemosyne, where, using Pathosformel as an operative principle, Warburg created a series of photographic montages placed on dark panels to show that throughout the centuries of history the same or very similar gestures or formulas were used in the visual presentation of basic human emotions.' Mnemosyne was a complex machine intended to surpass the limitations of discursive analysis and to stimulate in viewers the ability to make connections between gesture, memory and mimesis, so that they could eventually 'map out the visual memory of European culture, its origins and transformations.' In panel 5, for instance, Warburg presents a montage of Pathosformeln of women from works of different archaeological provenance (Greek ceramics, Roman sarcophagi, Pompeian frescos, etc) and thematic context (stories of Cybele, Niobe, Medea, Alcestis, etc) as a visual meditation on the essential forms of woman's vital experience such as panic, fury, crime, sacrifice (Figure 3.6).

12 Warburg 1999, 558.

13 Only recently have scholars begun to delve into the epistemological complexities of Warburg's project, read for years through the more positivistic, taxonomic, and textually oriented lens of his famous successors such as Panosfky or Gombrich. This Warburgian revival has produced extensive scholarship; most relevant here are: Didi-Huberman 2002; Michaud 2007; and Rose 2001.

14 Gombrich 1970, 223. 


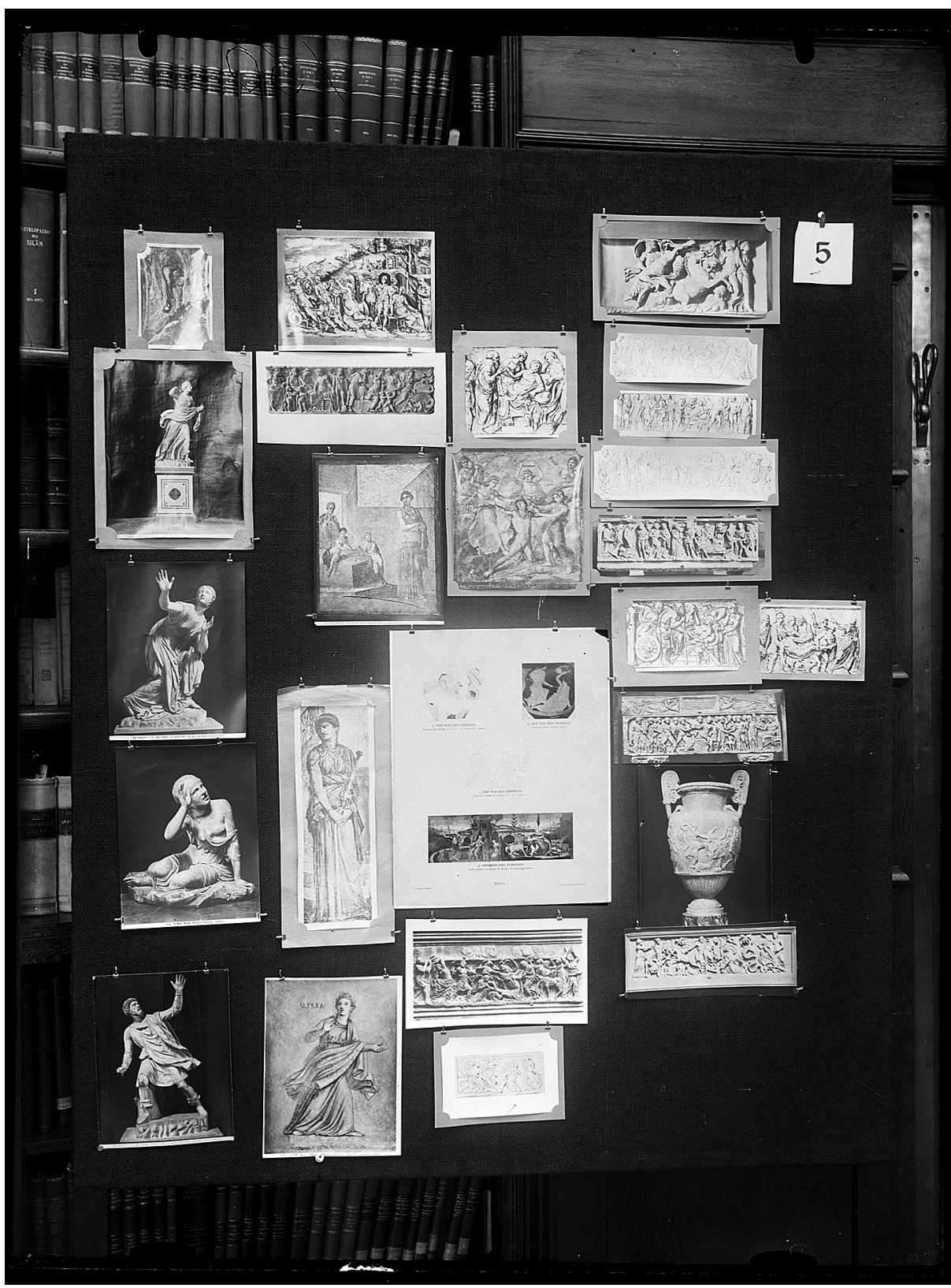

Figure 3.6: Panel 5 of the Mnemosyne Atlas. Formulas of female pathos. London, Warburg Institute. Photograph: courtesy of the Warburg Institute.

If Bertaux's beauté oubliée represents the acknowledged Apollonian inspiration for Moralejo's inquiry, Warburg's project emerges as its Dionysian 
repressed subtext. As in his case, Moralejo's interest in the question of the afterlife of antiquity centred on the observation of a trans-historical gestural vocabulary of the human expression that originated in the Greco-Roman world and re-emerged periodically in later works. But if Moralejo focused primarily on gesture as form and its implications for the history of style, Warburg was more concerned with gesture as psychic movement, and with the complexities of its recurrent historical materialisations at the intersection of iconography, cultural memory and human psychology. However, even if they were originally conceived as diagrams of classical formal sources, Moralejo's charts, seen from a Warburgian perspective, unintentionally double as psychic tableaux outlining a repertoire of Pathosformeln that defines the emotional space of the style (Figure 3.5). ${ }^{15}$ It is a space teeming with bodies imbued with the pathos of ancient art, and with faces whose Dionysian intensity leaves an indelible mark on those who walk along the Pilgrimage Road to Compostela, from the corbels of SaintSernin de Toulouse (Figure 3.7), to the capitals of San Martín de Frómista (Figures 3.4 and 3.8b), and the architectural sculpture in the cathedral of Santiago de Compostela. ${ }^{16}$ Embedded, therefore, in Moralejo's outline of the artistic genealogy of Hispano-Languedocian Romanesque sculpture, is a case study which provides a rich opportunity to explore the full potential of Warburg's theoretical paradigm - a case which is much more elegant in its formal premises and much more comprehensive in its historical and psychological ramifications than any that Warburg himself might have had at his disposal.

To explore the complex conditions involved in the reactivation of the Pathosformeln derived from the Orestes sarcophagus at the specific historical moment of the emergence of the Romanesque at the end of the eleventh century (such as formal processes, religious imagination, historico-political circumstances, and human psychology), I propose to build incrementally a new Mnemosyne panel that could be added to Warburg's unfinished 'ghost story for truly adult people' (Figure 3.8). With the sarcophagus as the classical, generative kernel, Romanesque works will be added in a series of analytical movements (motecta). When the panel is complete, at the end of this article, all those movements will relate to each other in complex contrapunctual harmonies which should be fully apprehended, to use a musical metaphor, like the

15 Thus they recall the famous tabular gestural taxonomies developed in the context of the clinical studies on hysteria conducted by Charcot at the Salpetrière. For the influence of Charcot's clinical studies on hysteria and his Iconographie photographique de la Salpetrière on Warburg's concept of the Pathosformel, see Schade 1995 and Didi-Huberman 2001.

16 For stylistic connections between the corbel from Saint-Sernin de Toulouse and the figural tradition inspired by the Husillos sarcophagus: Moralejo 1984b, 32-33. 


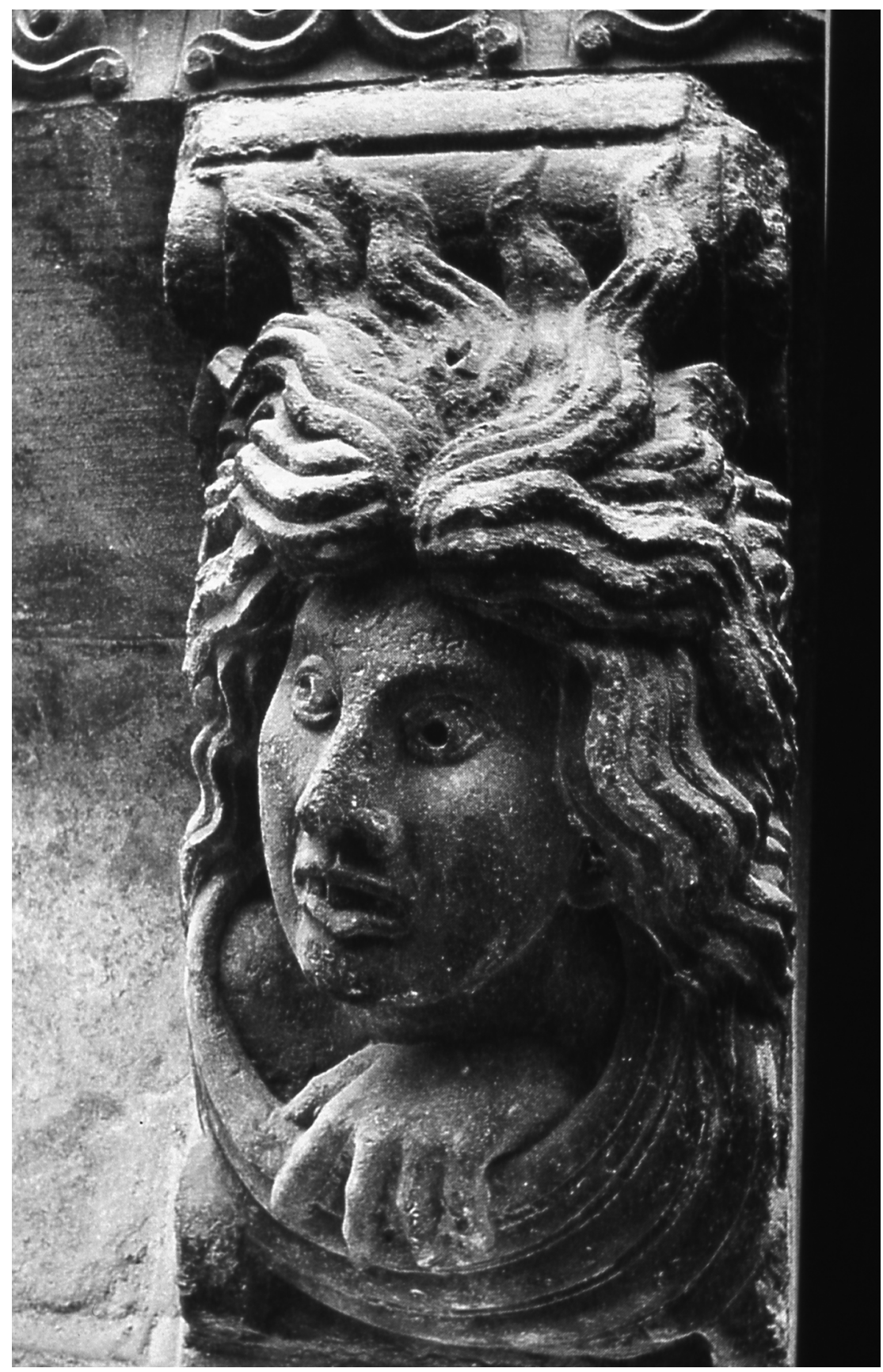

Figure 3.7: Corbel from the Porte Miègeville of Saint-Sernin de Toulouse. Photograph: author. 


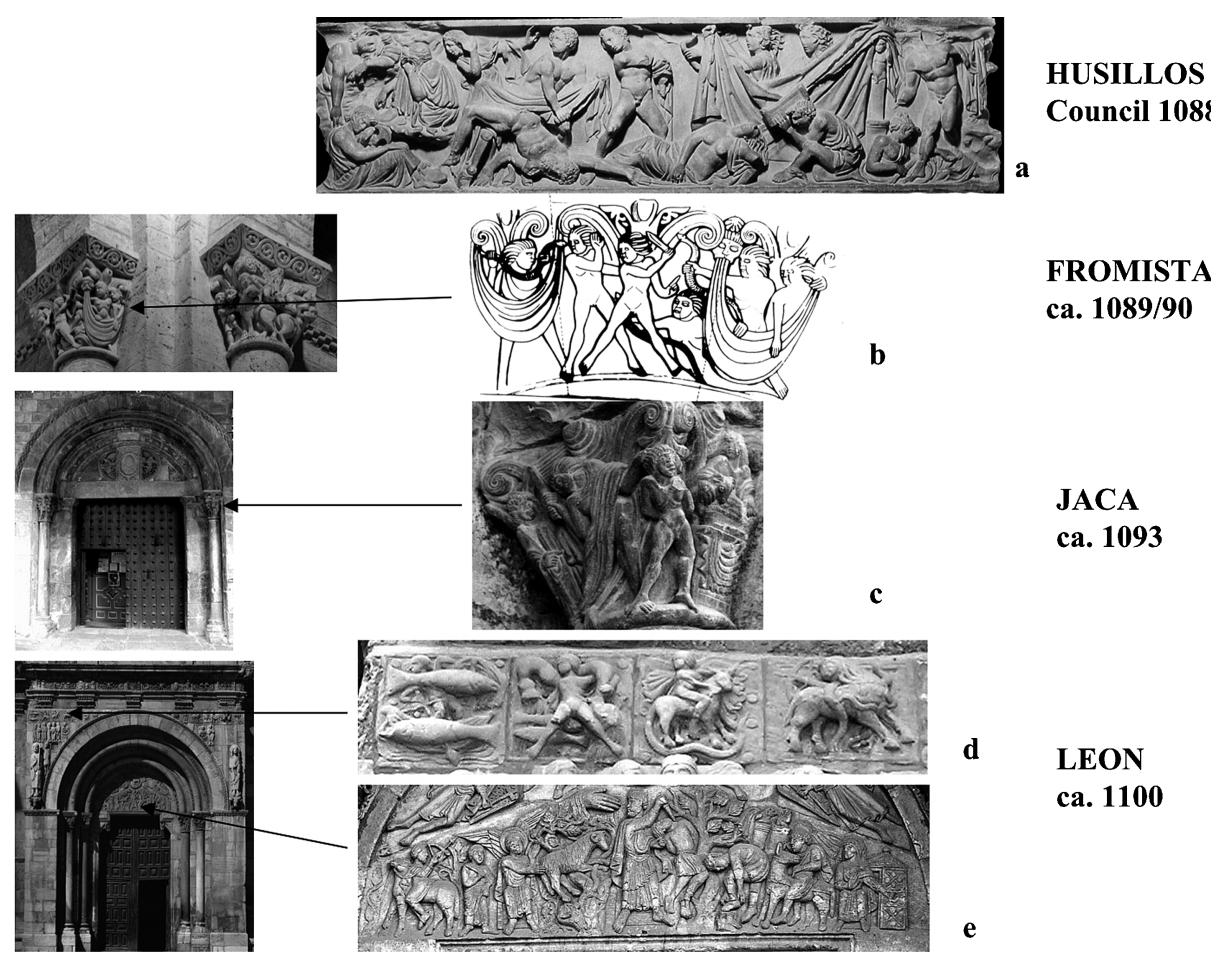

Figure 3.8: The Orestes sarcophagus in Spanish Romanesque sculpture a. Orestes sarcophagus (early second century A.D.). Madrid, Museo Arqueológico Nacional, inv. 2839. Photograph: courtesy of Museo Arqueológico Nacional. b. Capital with Cain killing Abel, central apse of San Martín de Frómista. Photograph: author. c. Capital with the Sacrifice de Isaac, South Portal of the Catedral de Jaca. Photograph: author. d. Frieze with the Signs of the Zodiac, Portal of the Lamb of San Isidoro de León. Photograph: author. e. Tympanum with the Sacrifice of Isaac, Portal of the Lamb of San Isidoro de León. Photograph: author.

polyphonic structure of a medieval motet. ${ }^{17}$ Over the cantus firmus of Moralejo's formal lineage, we will hear an elegiac chant around the themes of family crime and sacrifice - one that reverberates almost simultaneously and at different intensities, at four levels: mythical, biblical, historical, and historiographical.

17 Mnemosyne has been described as a symphony, see Gombrich 1970, 282. 


\section{Husillos: the Return of Orestes}

The starting place is the sarcophagus itself. Drawing principally on Aeschylus's famous trilogy, The Oresteia, its scenes represent the revenge of Orestes and his subsequent quest for expiation (Figure 3.1) ${ }^{18}$ From left to right, the narrative unfolds chronologically in a continuous series of interconnected tableaux, beginning with a peaceful scene where the Erinyes, goddesses of revenge, rest quietly before the crime around the funerary cairn of Agamemnon, who had been assassinated by his wife Clytemnestra and her lover Aegisthus. Then, suddenly, in the centre, the drama explodes into a chiastic movement, springing from the double portrait of Orestes in his murderous rampage to avenge his father's death, and the slain bodies of Clytemnestra and Aegisthus, toppled from his throne. ${ }^{19}$ Forming emotional brackets to this central scene are two supporting characters, which will have illustrious Romanesque descendants, an old nurse who shields her face from the violence, and a manservant hiding behind a stool beside Clytemnestra's corpse.

The Roman artist cleverly incorporated subtle elements of the Aeschylian mise-en-scène: for instance the cloth with which Orestes cleans his sword after killing Aegisthus recalls the carpet and robe which Clytemnestra used in Agamemnon's murder, and so expands the dramatic span of the story by introducing a reminder of the earlier crime that had sparked the whole cycle of revenge. Another dramatic peak of the play is evoked by the figure of Orestes brandishing his sword over Clytemnestra's partially naked body. Despite the fact that matricide seems to have been committed already, Orestes appears still caught up in the agonising moment of hesitation that preceded the crime, when the queen pleaded for mercy by showing him her breasts, to remind him of her motherhood. It is then that Orestes utters the most famous line of the play 'What am I to do Pylades? Be ashamed to kill my mother?' If we identify the figure to the left of Orestes as his companion Pylades, that is exactly the tragic question reverberating through the reliefs. When viewers of the sarcophagus follow the interpretative sequence movement activated by the multivalent visual narrative of the frieze (Orestes progressively killing his mother and her lover, Orestes posing the 'tragic question' to Pylades, the piece of cloth that recalls the

18 First performed in 458 B.C., The Oresteia inspired a lasting iconographic tradition. From the Greek stage, the saga of Orestes entered Latin literature, and during the Hadrianic Hellenic revival it became the subject of a magnificent series of Roman sarcophagi, of which the Husillos sarcophagus is a prime example: See Toynbee 1934, 166-77, McCann 1978, and Neils 1984.

19 An alternative interpretation sees the two figures as Orestes, centre, and his friend Pylades, to the left. 
original crime), they can experience the sculptures in their dynamic dimension, as a true 'life' performance of the play.

The next episode on the sarcophagus (to the right of centre) begins with the entrance of two Furies who, woken by the blood spilled in matricide, pursue Orestes, brandishing a snake and a torch. Finally, the right end of the frieze introduces the first stage in the process of purification - Orestes' visit to the temple of Apollo in Delphi: en route to Athens, he steps gingerly over a sleeping Fury who has fallen victim to Apollo's spell.

The short sides of the sarcophagus represent the expiatory rites that would eventually cleanse Orestes of his crime. The right side features a scene showing Orestes and Pylades being captured by the Tauri, who have the custom of sacrificing all strangers to Artemis, but Iphigenia, the high priestess of the goddess, eventually recognizes her brother and the three manage to escape to Athens carrying the sacred statue (Figure 3.2). On the left, Athena casts the deciding vote in favour of Orestes at the trial of the Areopagus, which would put an end to his persecution by the Erinyes (Figure 3.3).

Not until the nineteenth century was the iconography of this typology of socalled 'Orestes sarcophagi' determined with any certainty. Even the knowledgeable seventeenth-century Roman antiquarian Giovanni Bellori failed to give a satisfactory interpretation of an almost identical piece housed at the Palazzo Giustiniani. ${ }^{20}$ In his Admiranda Romanorum antiquitatum ac veteris sculpturae vestigia (1693), Bellori wrote a poetic commentary to accompany a delicate engraving of the sarcophagus by Pietro Santi Bartoli, where he emphasised the themes of crime and sacrifice as central to its meaning. ${ }^{21}$

But more than a century before Bellori, and writing about the Husillos sarcophagus, the Spanish humanist Ambrosio de Morales had come closer to the original meaning of the typology by framing the themes of crime and sacrifice within the context of an interfamilial conflict. Morales drew upon his knowledge of Roman history, mediated through Livy, to speculate that it might represent the story of the Horatii and Curiatii (described in Ab Urbe Condita I, $24-26$ ). ${ }^{22} \mathrm{He}$ identifies the central figure (of Orestes who had killed his mother Clytemnestra) as Horatius who had just murdered his sister Camilla claiming 'So perishes any Roman woman who mourns the enemy,' for she had shown

20 Although its iconography was not properly understood during the Renaissance, this sarcophagus was revered by many artists who used it as a source of figural models: see Bober and Rubinstein 1986, 137-138.

21 For the online edition of the Admiranda Romanorum antiquitatum, with an image of Pietro Santi Bartoli's engraving, see the Corpus Informatico Belloriano http://biblio. signum.sns.it/cgi-bin/bellori//blrCGI?cmd $=1 \& \mathrm{w}=12 \& \mathrm{u}=$ Palazzo+Giustiniani. + Stra ge\&pg $=052$

22 Ambrosio de Morales visited Husillos in the course of his trip, at the command of Philip II in 1572, to document the treasures of his kingdom: Morales 1765 [1977], 26-27. 
grief at the death of one of the Curiatii to whom she was betrothed. This story has some parallels with Orestes's tragedy, because, like Orestes, Horatius should have been condemned to death for killing his sister but was absolved because of the motivating circumstances and the advocacy of his father. To expiate his crime, Horatius' father obliged him to carry out a series of sacrifices, amongst which was to walk under a beam 'as if set under the yoke.' Morales identifies the figure on the sarcophagus of the crouching servant with a stool as Horatius passing under this beam, which came to be known as the tigillum sororium (sister's beam). In sum, Morales' knowledge of an ancient text (Livy) allowed him to identify a classical story of family crime and expiation similar to the one that was actually represented in the sarcophagus.

But more relevant to this inquiry is the process of interpretation that enabled Morales to access the core of Orestes' story, exclusively through the evocative power of a Pathosformel. He identifies the Erinyes who sleep around Agamemnon's cairn in the sarcophagus as mourners grieving the death of Camilla; he then identifies as her corpse the body of the sleeping Erinys lying by Aegisthus'; and he interprets his body as that of the slain Curiatius. At this point Morales makes a startling comment about the crouching Erinys whose face is hidden by a veil, saying that 'she conveys more sadness than any of the other figures whose faces are visible to us. It is as if the artist wanted this figure to be the Agamemnon of Timanthes, whose grief was covered with a gesture in order to be more intensely revealed by art. ${ }^{, 23}$ The humanist recalls here the famous story of the Greek painter Timanthes of Sicyon whose artistic capacity to represent grief-stricken faces reached its limits when he attempted to render that of Agamemnon at the sacrifice of his daughter Iphigenia, deciding finally to cover his face with a veil. ${ }^{24}$ This painting is now lost but a possible echo survives in works such as a fresco of the Sacrifice of Iphigenia from the House of the Tragic Poet in Pompeii and a mosaic of the same theme from Ampurias, both showing Agamemnon covering his face with a veil, in a gesture that closely resembles that made by the Erinys in the sarcophagus. ${ }^{25}$ It is a testimony to the evocative power of the images of the sarcophagus that the gestural expression of the Erinys could bring to mind for Morales the sacrificial drama (the murder of Agamemnon) at the origin of the actual story represented in the frieze. Here Morales' interpretation shows a process of transmission whose complexity

23 Morales 1765 [1977], 26.

24 See Pliny (Naturalis Historia, 35.73), Quintillian (Institutio Oratoria, 2. 13. 13) and Cicero (Orator, 74).

25 For an illustration of the Sacrifice of Iphigenia from Pompeii, now in the National Archaeological Museum of Naples, see Prado-Vilar 2008, 179, fig. 6. For the mosaic from Ampurias, see Blázquez 1993, 388-389. For later use of the motif of the veiled face to represent inexpressible grief, e.g. Nicolas Poussin in his famous Death of Germanicus, see Montagu 1994, and Crow 1999, 79-103. 
surpasses any example studied by Warburg: we see how the Pathosformel invented by Timanthes as the paradigmatic representation of the inexpressibility of paternal grief was textually transmitted by several Roman authors (Pliny, Quintillian, Cicero) and visually recreated by Pompeian painters, who inserted the image of the veiled Agamemnon in their representations of the myth. Later, in the context of the Greek revival of the time of Hadrian, the Pathosformel of the veiled face was deployed by the sculptors responsible for the Orestes sarcophagus, which much later on would end up in medieval Husillos. Arriving there centuries later, Morales observed the Pathosformel of the veiled face, recalling immediately, through textual memory and mimesis, the story of Timanthes' veiled Agamemnon. Therefore, remarkably, the Pathosformel caused Morales to invoke the 'ghost' of Agamemnon in the very same location on the sarcophagus where, unbeknown to him, the cairn of the murdered king is represented. ${ }^{26}$

Morales' account is also illuminating about the different reception accorded to the sarcophagus by ecclesiastical dignitaries and artists. An Italian church official, Cardinal Poggio, praised the work saying: 'this tomb deserved to be in Rome among the most precious antiquities preserved there, because it is as good as all of them.' And a prominent Spanish Renaissance artist, Alonso de Berruguete, was similarly admiring: 'I haven't seen anything better in Italy, and a few things which are as good.' In addition to the opinion of such well-informed patrons and artists, Morales relates a personal anecdote that attests to the mythopoetic power of the work: noting that the head of Orestes in the Delphi scene seems to have been deliberately struck off, rather than broken accidently, he concludes that this must have been the act of an artist eager to take it as a 'token of such a marvellous work. ${ }^{27}$

In trying to match the gestural language of the sarcophagus frieze with a written source they deemed appropriate to its original context, these commentators allow us to reflect on the various responses of medieval audiences, which ranged from learned appraisals based on classical sources to

26 This analysis helps elucidate an aspect of my interpretation of the Husillos Orestes frieze about which scholars disagree. Toynbee $(1934,167)$, amongst others, suggested that the mound around which the Erinyes rest represents Agamemnon's cairn, arguing from comparison with other types of Orestes sarcophagi which at that point show, instead, Agamemnon's ghost. I would suggest that the Roman sculptors who designed the typology of Orestes sarcophagus to which the Husillos example belongs, intentionally included the Pathosformel of the veiled face at the site of Agamemnon's cairn, as a visual trigger to set off in viewers familiar with the story of Timanthes' Agamemnon, the same interpretive process that Morales later underwent: i. e. to recall Agamemnon's ghost, and by extension Iphigenia's sacrifice - the crime that initiated the tragic cycle represented on the reliefs.

27 These quotes in Morales 1765 [1977], 27. 
popular anecdotes inspired by the mythopoetic power of its imagery. ${ }^{28}$ In the absence of documentary records informing us of the medieval reception of the Orestes sarcophagus, the principal evidence for the continuous interest in the interpretation of its imagery is the trail of Romanesque works inspired by its reliefs. Indeed, it is no coincidence that themes of genealogy, crime and sacrifice are at the core of the iconography of the three Romanesque works more intensely indebted to the imagery of the sarcophagus: the capital from the apse of San Martín de Frómista (Figures 3.5 and 3.8b, depicting Cain killing Abel), a capital from the Cathedral of Jaca (Figure 3.8c), and the tympanum of the socalled Portal of the Lamb of the basilica of San Isidoro in León (Figure 3.8e), both representing the Sacrifice of Isaac. It is as if style and iconography, mimicking the Erinyes, were relentlessly following the trail of family blood.

\section{Frómista: the Mark of Cain}

Appropriate to its position at the head of the formal genealogy which sprang from the imagery of the sarcophagus, the capital from the church of San Martín de Frómista also emerges as the closest conceptual translation of its iconographic message into a new Christian context. ${ }^{29}$ Indeed, both the sarcophagus and the capital deal with themes of the shedding of family blood and its divine punishment. The iconography of the capital has long eluded scholars, largely because the two nude figures on it were defaced (in what seems to have been a deliberate act of censorship during a restoration of the church in the early twentieth century), and their original gender has been disputed.

The capital visible in the apse of the church today is a copy, made before the two nudes on the original were destroyed: it shows them as a man and a woman

28 For an example of the mythopoetic power of figures on Roman sarcophagi to spark biographical legends around the medieval personages who re-used them for their burials, see Moralejo 1984, 189-90.

29 San Martín de Frómista was a small Benedictine community founded by Alfonso VI's grandmother, Muniadomna, Countess of Castile and widow of Sancho III the Great of Navarre. Through her, Fernando I, Alfonso's father, inherited the Kingdom of Castile. In her foundational charter, Muniadomna expressedly bequeathed San Martín de Frómista to her 'stirpe' entrusting her descendants with its care and aggrandisement as a special dynastic possession. Her will of 1066 mentions work under construction, but the present church was built c. 1090 and belongs, typologically and stylistically, to a group of churches in the area of Tierra de Campos (Palencia) connected with the Leonese dynasty. All of these churches underwent building campaigns in a new mature Romanesque style right after the council of Husillos (see Prado-Vilar 2008, 183-184). 
(Figure 3.4d)..$^{30}$ Moralejo, and every other scholar after him, never questioned the reliability of this copy. 'The calm nudes, man and woman,' he wrote, 'who find themselves threatened by sinister individuals flourishing serpents, seem to suggest an allegory of the fallen human condition, impossible to translate verbally. ${ }^{31}$ There is in fact a photograph of the capital taken before its defacement, which shows one of the nudes (clearly male), but, unfortunately, only part of the other (Figure 3.4b). ${ }^{32}$ Yet it clearly shows how far the copy diverged from the original, and particularly how the restorer engaged in a 'genital reconstruction' of what he thought was a female figure. ${ }^{33}$ But this figure was probably male like the other (although the restorer may have been confused because its penis was missing and because the medieval sculptor had exaggerated the muscled chest of the Roman figures he was copying, so they looked rather like female breasts).

Analysis of the process by which individual figures from the Orestes sarcophagus were assigned new roles within the thematic environment of the capital leaves no doubt that this scene represents Cain killing Abel. On the capital Cain adopts the heroic pose of the murderous Orestes, while the terrified nurse of the sarcophagus becomes Abel recoiling from the blow. ${ }^{34}$ More startling is the transformation of the figure of Aegisthus, which has been turned upside down on the capital to join the demonic forces that emerge from the underworld to punish Cain. This metamorphosis was with all probability suggested by the biblical passage (Genesis $4: 3-10$ ) that describes how Abel's blood cried out to denounce the crime and curse the murderer.

Comparison with two other artworks, which feature separate episodes of this biblical narrative, shows quite how brilliantly the whole story was visualised at Frómista. The first is a capital from the cathedral of Saint-Lazare in Autun showing God asking Cain for his brother, whose corpse lays hidden in the bushes, his legs partially visible in the frontal face of the capital while the rest of the body occupies the lateral face. ${ }^{35}$ The other is a drawing from an early eleventh-century Anglo-Saxon manuscript now in the Bodleian Library (MS

30 For the socio-historical context of the restoration of San Martín de Frómista, see the two collections of essays published on the occasion of its 100 anniversary: Frómista 2004; and San Martín de Frómista 2005.

31 Moralejo 1994b, 211.

32 The photograph was first published in Serrano Fatigati 1901.

33 He inflated the genital area and inserted a slit where there was originally none, resulting in a strange unicum in 'medieval' vaginal iconography. For medieval vaginal iconography, see Caviness 2007.

34 The medieval artist adopted the sword from the Orestes sarcophagus to fill the gap in the biblical narrative which says nothing of the instrument Cain used. For the iconography of Cain's weapon, see Schapiro 1979, 249-65; and for the blade as weapon in twelfthcentury Iberian examples, see Patton 2005.

35 See Grivot and Zarnecki 1961, 68; and Prado-Vilar 2008, 181, fig.9. 
Junius 11, fol. 49) which focuses on the moment when the blood of Abel (represented in anthropomorphic form as is typical in medieval iconography) denounces the crime to God. ${ }^{36}$ In contrast, the Frómista artist, inspired by the narrative theatricality of the Hadrianic reliefs, manages to create a more dynamic composition that combines three episodes in one explosive moment: Abel's murder, the denunciation of the crime to God, and the following curse, resulting in one of the most spectacular evocations of Abel's death in medieval art.

The Furies of the sarcophagus, who in classical mythology were specifically devoted to avenging the shedding of kindred blood, re-emerge on the capital, with function and meaning unchanged, as if their persecuting rage had carried them directly from mythical to biblical times. ${ }^{37}$ This iconographic continuity from sarcophagus to capital parallels their survival in written texts, notably in their description in Isidore's Etymologies which was widely read through the Middle Ages, and specially in eleventh-century Castile:

They also say that the three Furies are women with serpents for hair, on account of the three passions that give rise to many disturbances in people's spirits, and they sometimes so drive a person to do wrong that they allow him to give no consideration to his reputation or his own danger. The passions are Anger, which desires revenge, Desire, which wishes for wealth, and Lust, which seeks pleasure. They are called Furies (Furiae) because they strike (ferire) the mind with their goads and do not allow it to be tranquil (VIII. Xi. 95). ${ }^{38}$

As in the Greek drama, where the Erinyes pursue Orestes relentlessly, on the Frómista capital they seem to enforce God's curse to Cain, 'you will be a fugitive and a wanderer on earth' (Genesis 4:12). The disgrace that befalls sinners, condemned to wander in the wilderness for letting animal impulses control their actions is, appropriately, the theme of the adjacent capital, by the same sculptor - the original is also in the Museo de Palencia, replaced by a copy in the church (Figure $3.8 \mathrm{~b}$ ). This group of partially naked men riding fierce lions brings to mind 'the passions [of] Anger, which desires revenge, Desire, which wishes for wealth, and Lust, which seeks pleasure,' described by Isidore in the aforementioned passage.

The identification of the iconography of the famous capital as Cain's murder of Abel is confirmed by its narrative and allegorical relationship with neighbouring capitals. The narrative context is defined by the axis that connects this capital with the capitals of the nave, where we find, supporting the arcade that gives access to the crossing, a pair depicting two other episodes from Genesis: the Temptation of Adam and Eve (north) and the Reprimand and

36 See Kauffmann 2003, 37-55, and Prado-Vilar 2008, 181, fig. 10.

37 For the function of the Erinyes in the Aeschylan stage, see Frontisi-Ducroix 2007.

38 Isidore 2006, 189. 
Expulsion from Paradise (south). In turn, the allegorical context is provided by its pendant capitals on the north side of the apse: one shows a series of heraldic birds, probably doves - an iconography of clear Eucharistic/sacrificial connotations appropriate to this area of the church - and the capital next to that, which has lush vegetal decoration evoking paradise. ${ }^{39}$ So if the figurative programme of the south side of the apse (Cain killing Abel and men riding lions) focuses on the martyrial and penitential dimension of sacrifice (Abel as a type of the first martyr and prefiguration of the Passion of Christ), then the north side focuses on its salvific and paradisiacal aspects, through eucharistic birds and vegetation.

Located in the most prestigious area of the church, the Cain capital is not only the masterpiece of the sculptural decoration of San Martín but also the cornerstone of its iconographic programme. To be sure, this direct quotation of the frieze of the Orestes sarcophagus in the most visible place of the church at Frómista, in the aftermath of the Council of Husillos, might respond to a more specific set of circumstances than mere aesthetic appeal for the classical model. The capital might have been created as a lieu de mémoire meant to recall its ancient model, not only artistically but also iconographically, contextually and historically. As mentioned earlier, the circumstances that compelled Alfonso VI to summon the council at Husillos were extremely grave as the unity and stability of the kingdom had been seriously threatened by political insurgency (a rebellion of Galician nobles), and ecclesiastical turmoil (the bishops' resistance to the adoption of the Roman rite and to the advance of Cluniac influence). Various pieces of surviving evidence show how the council then dealt with political pacification, reorganisation of the church, and the resolution of conflicts over ecclesiastical jurisdiction. ${ }^{40}$ So, for those who attended, the imagery of the sarcophagus must have been artistically impressive and also very evocative in its significance. In the eleventh century, in a church setting, images apparently representing a family crime associated with scenes of offering and sacrifice would probably recall episodes from the cycle of Cain and Abel - the nudity of the figures, rather than signalling a referent to classical antiquity, might, in that context, have suggested a Biblical narrative of origins. ${ }^{41}$ And so the Frómista artist, following the directions of his patron, might have

39 Illustation in Prado-Vilar 2008, 183, fig. 12.

40 For the historical significance of the council of Husillos, see above, n. 3.

41 For a comparison between the scene of Athena at the trial of the Areopagus from the Husillos sarcophagus (Figure 3.2) and a compositionally similar Romanesque representation of the Offering of Cain and Abel in a twelfth-century capital from Moutiers Saint-Jean, now at the Fogg Museum, Harvard University, see Prado-Vilar 2008, 184, fig. 13. 
deliberately copied the 'Orestes' scenes for the iconographic value that had been assigned to it in Husillos during the council.

It is, therefore, not a coincidence that, like the council of Husillos, with its aims of peace and stability, the iconographic programme at Frómista presented biblical and moral condemnations of fratricidal violence, and the church as the agent restoring peace. ${ }^{42}$ The Genesis capitals of the crossing illustrate the fall of man, its causes and consequences: pride, discord, violence, damnation. The pairs of capitals decorating each of the interior arcades of the two entrances articulate moralising messages by establishing deliberate compositional and thematic connections with the crossing capitals, whose Biblical stories provide the Scriptural background.

In sum, the direct paraphrase of the Husillos Orestes sarcophagus in the capital at Frómista, and the connections between the iconographic programme of San Martín de Frómista and the issues discussed at the council of Husillos, opens the possibility to speculate that the Frómista programme might actually have been inspired by the council's pacifying mission. In other words, the council's proceedings may still survive at San Martín de Frómista, written in stone in a new Romanesque language, and with the Cain capital as its seal of provenance.

The council of Husillos also provides clues about the kind of personal and institutional connections that might have brought to Spain an artist such as the sculptor of the Cain-Orestes capital, whose artistic genealogy has been traced back to the figural arts of Gascony and, particularly, to the naturalistic pictorial tradition represented by the magnificent Beatus of Saint-Sever (Paris, Bibliothèque nationale, Ms. Lat. 8878 , fol. 85 , ca. 1070). ${ }^{43}$ This was made by an artist, Stephanus Garsia, who had a sensibility for the tautness of the flesh, the diaphanous fluidity of folds and the emotional extremes of the human experience. It is from that teeming ferment of Pathosformeln, beautifully illustrated by the miniature of the Flood from the Beatus, where we find the

42 The historiated capitals at Frómista articulate the interior space of the church in what Moralejo rightly understood as a series of 'programmatic sequences' (Moralejo 1990, 23). Figured capitals concentrate in meaningful groups in three principal areas: the crossing, where, as we have seen, there are capitals depicting episodes from Genesis; the interior arcade of the northern entrance (the access to the laity) with capitals featuring popular fables and moralising themes; and the interior arcade of the southern entrance (the access for the monks) decorated with capitals featuring ecclesiastical themes. For a detailed discussion of this iconographic programme and its historical significance in the context of eleventh-century Romanesque, see Prado-Vilar 2008, 182-184.

43 For the connections between Frómista and the Southwest of France, see Moralejo 1987, 94-95; and Moralejo 1985, 77-80. 
DNA of the eye and the hand of the Orestes-Cain master. ${ }^{44} \mathrm{He}$ may have arrived in Husillos with his patron for the council, and there found the myth that changed both his life and the art of the time. ${ }^{45}$

\section{Jaca: the Inventory of Forms}

During the time that the group of artists trained at Fromista moved along the pilgrimage road to Jaca, the forms of the Husillos sarcophagus had come to dominate the visual morphology of their style - nudes in chiastic poses with thick, deeply-carved hair, undulating draperies, and figures brandishing serpents are ubiquitous (cfr. Figure 3.5). ${ }^{46}$ For this reason Moralejo called the artist responsible for the Cain-Orestes capital at Frómista 'The Jaca Master'.

But there was a substantial difference, for unlike the sculptor of the Frómista capital, who looked at the Orestes frieze as a compositional and iconographic unit, the masters of the Jaca workshop used the images as a repertory of forms, dissecting its individual Pathosformeln to recast them in different Biblical roles (such as Balaam, Daniel, and Habbakuk). Using the ancient forms in this way, the masters of Jaca emerge as the direct forerunners of Renaissance artists, such as Raphael and Titian, who would later subject other ancient Orestes sarcophagi to a similar taxonomic gaze. ${ }^{47}$ To the transitional period between the Middle Ages and the Renaissance, belongs a series of drawings compiled in the so-called Vallardi codex, which artists of the circle of Pisanello produced to use for figurative models. ${ }^{48}$ One folio gives an idea of the repertory of models that might have been used by the Jaca sculptors. It shows three figures copied from an Orestes sarcophagus: one brandishing a club, which is taken from the central Orestes; a woman derived from the figure of Aegisthus, here returned to life as in the Frómista capital; and a crouching man that recalls the figure of the servant. ${ }^{49}$

44 An illustration of this miniature in Prado-Vilar 2008, 185, fig. 16. For the interest of Stephanus Garsia in recycling motifs from antique sources, especially from the iconography of battles, see Werckmeister 1973, 612-616.

45 For a possible patron, Bernard of Sédirac, a prominent Cluniac monk with Gascon connections who became archbishop of Toledo and attended the council of Husillos, see Prado-Vilar 2008, n. 59, and Prado-Vilar 2009, n. 36.

46 For a comprehensive discussion of the chronology and stylistic filiation of the sculpture of Jaca, see Moralejo 1979, and 1984.

47 For Titian, see Brendel 1955. The figure of Orestes/Pylades provides the blueprint for the Bacchus in his Bacchus and Ariadne at the National Gallery of London.

48 For this codex, now in the Louvre (Cod. Vallardi, inv. 2397v), see Scheller 1995, $341-$ 356.

49 Illustration in Prado-Vilar 2008, fig. 17. 
The transformation of the legacy of the Husillos sarcophagus into a workshop undertaking must have occurred in an intermediate stage situated chronologically between Frómista (c. 1089/90) and Jaca (c. 1093/94), which is now difficult to locate but, for reasons I have outlined elsewhere, we can point to San María la Real de Nájera as a good candidate - an important monastery on the route from Palencia to Aragón, which had become, since its incorporation to the Kingdom of Castile in 1076 and its donation to Cluny in 1079, one of the most important monastic centres of the kingdom. ${ }^{50}$ We might speculate that it was in Najera where the Orestes-Cain master passed on his knowledge to younger members of his workshop who would then exploit it with a new vitality. The principal master of Jaca would belong to this new generation, for his work exudes, as Marcel Durliat perceptively observed 'un esprit de jeunesse, une vivacité et une spontanéité remplis de séduction. ${ }^{31}$

If the Nájera capital is the missing link between the sculpture of San Martín de Frómista and that of the Cathedral of Jaca, a capital from the South Portal of the latter provides a link towards the future (Figure 3.8c). It is an artistic experiment that foreshadows the high levels of formal and conceptual sophistication, which this new generation of artists would reach in their dialogue with the Husillos sarcophagus when they finally returned to the Kingdom of León. On this capital, the heroic pathos of the Orestes frieze is fully revived when its morphology and syntax are put to serve the most gripping family drama of the Old Testament, the sacrifice of Isaac (Genesis 22). The sculptor of this capital radically transformed the central group of the sarcophagus, so that the nurse turned into the figure of Abraham, who holds by the hair the naked body of Isaac, which in turn was modelled on the central Orestes. The figure of Pylades reappears as a woman holding a ram by the altar (identical disposition of head and upper body and drapery covering the lower portion). The result is a dramatic immediacy not found in other Romanesque representations of this theme.

This led Moralejo to relate the capital to a personal statement written by King Sancho Ramírez, the patron who oversaw the early construction of the cathedral. In a charter of 1093, Sancho Ramirez offered his own son Ramiro as oblate to the monastery of Saint-Pons de Tomières, allegedly as a sacrifice to gather divine help to fight the enemies of the Christians. ${ }^{52}$ As was standard in this type of donation, he compared himself to Abraham who was willing to immolate Isaac. Yet the terms of this invocation more clearly recall the

50 A single capital with vegetal decoration, now preserved in the Cathedral of Jaca, stands as a token of its Romanesque fabric and shows direct connections with both Frómista and, specially, Jaca (an illustration in Prado-Vilar 2008, 186, fig. 18).

51 Durliat 1990, 220.

52 Moralejo 1985, 30-32. For an edition of this document, see Lacarra 1946. 
motivation behind the mythological sacrifice - of Iphigenia by Agamemnon that was the source of imagery which permeates the composition of this capital.

In addition to these formal echoes of the sarcophagus frieze give the story of Orestes a subliminal 'presence' on the capital, the woman derived from the figure of Pylades offers a more direct point of connection. In form and iconography, she links the biblical sacrifice, which is explicitly represented, and the mythological sacrifice which is latent. To be sure, she does not occur in the biblical narrative (which simply says that the ram appeared caught up in a thicket) and more closely brings to mind the figure of Artemis who saved Iphigenia by sending a deer to be killed in her place. The iconography of this episode was widely disseminated in antiquity through works in various media, such as aforementioned painting from the House of the Tragic Poet in Pompeii or the mosaic from Ampurias. Although the classical iconography of the Sacrifice of Iphigenia has no direct relation to the Abraham capital at Jaca, distant echoes of it resonate in the figure of this woman. ${ }^{53}$ This brief analysis of the complex network of formal, iconographic and historical threads that meet in the Jaca capital underscores its status as a lieu de mémoire that holds the 'essence' of the concept of ritual sacrifice in Mediterranean culture.

Compositionally, iconographically, and stylistically, the design of the South Portal of Jaca is an essential introduction to the next work in the Romanesque succession from the Orestes sarcophagus, the South Portal of the Basilica of San Isidoro in León, which is also known as the Portal of the Lamb (c. 1100).

\section{León: the Iconology of the Interval}

The product of a workshop trained in Jaca, the Portal of the Lamb at León reproduces in its general layout the original arrangement of the South Portal of Jaca cathedral, but on a monumental scale and with a more extensive sculptural programme. It has a richly carved tympanum featuring the Agnus Dei and the Abraham story, and a large frieze above the doorway which depicts the signs of the Zodiac (Figures $3.8 \mathrm{~d}$, e).

Moralejo noted that the figure of Aquarius in this frieze derived from the central Orestes of the sarcophagus (Figures 3.5 and 3.8d)..$^{54}$ However, the influence of the classical reliefs is more extensive, and can be felt in the syntax that connects Aquarius with its adjacent signs: Sagittarius and Capricorn, with wild hair and threatening attitudes (using arrows instead of serpents) mirror the two Furies who charge towards Orestes in the sarcophagus, while behind the

53 For further details on the complex network of exegetical and iconographic traditions that inform the presence of this woman in the Jaca capital, see Prado-Vilar 2008, 185-186.

54 Moralejo 1977. 
fish in the sign of Pisces, is a figure (a fisherman?) which faithfully reproduces the backward movement of the old nurse. Furthermore, the curve of the cloth that links Pylades and the nurse on the sarcophagus is reproduced in the Pisces panel to create the shape of a boat (just behind the lower fish). So here the artists show an understanding of the compositional syntax of the Orestes frieze and of the dynamics generated by the correlation among the figures that transcends the simple cataloguing of Pathosformeln. This offers a preview of what they accomplished in the tympanum.

Although, surprisingly, this tympanum has never been mentioned in connection with the Husillos sarcophagus, it is unquestionably the Romanesque work that most profoundly engages the classical model (Figure 3.7d). The Sacrifice of Isaac is situated at its centre, at the intersection of two axes, a vertical one encapsulating the Eucharistic idea of sacrifice by drawing a typological connection with the Agnus Dei, and a horizontal one that dramatises the theme of genealogy and its implications for salvation history by playing out the contrast between Abraham's two sons, Isaac and Ishmael. The biblical narrative that unfolds in the horizontal axis is rare in Romanesque tympana. From right to left appears Sarah, seated in front of a tent house overseeing the departure of her son Isaac. Next he is shown removing his shoes to enter the sacred ground where the sacrifice will be performed (the repetition of Isaac on his way to the sacrifice and his representation with a halo stress the Christological implications which are explicitly symbolised in the vertical axis). In the centre is Abraham at the fateful moment in which he is stopped by God's injunction. To his left, an angel offers the lamb that will take the place of Isaac. Next to the angel is Abraham's slave concubine Hagar and her son Ishmael, both represented following the biblical narrative, as they wander in the wilderness of Beersheba.

The elongated field of the tympanum allowed the artist to adopt faithfully the sarcophagus frieze as a compositional blueprint, reproducing closely the poses and positions of individual figures. From right to left, the figure of Sarah, extending her left arm backwards as she turns her head towards the direction of the action, is a variation of Orestes at Delphi; Isaac taking off his sandals recalls the crouching pose of the servant; the figure of Abraham is a clothed version of the central Orestes, as if he had grabbed from the ground the corpse of Clytemnestra, here transformed into Isaac; the Angel, with his right arm crossing over his chest to bring forth the lamb, replicates the position of the Orestes/Pylades; and finally, Hagar strikes a pose similar to the sleeping Fury on the left end of the sarcophagus.

The León artist also shows a masterful understanding of the rhythmic cadences of the Roman sarcophagus reliefs. In both works, the forceful chiastic centre sets off a kinetic reaction that ripples laterally in undulating sequences. The ample curves of fluted drapery created, on the right side of the sarcophagus, 
by the cloth hanging before the Furies and the fabric held by the Orestes at Delphi are echoed in the tympanum by the rhythmic waves described by the tree branches, Isaac's discarded garments suspended between the branches and the altar, and his billowing cape as he rides off to Mount Moriah. Similarly, on the left side of the tympanum, the elongated body of the sheep held by the angel occupies the same position as the stretched cloth that connects Aegisthus's corpse to the hand of his murderer in the sarcophagus. At an even more subtle level, the tympanum emulates the narrative technique of the sarcophagus down to its clever use of syncopated temporality. The replication of the figure of Isaac progressing rapidly in three different temporal sequences recalls the heightening rhythm effected by the triplication of the figure of Orestes, from his single appearance at Delphi to his doubling during the killing spree.

Yet the most brilliant artistic and conceptual communion between the tympanum and the sarcophagus occurs in an empty space - the charged area where the gaze of the sacrificer meets the hand that tries to stop him. The hand of the nurse facing Orestes/Pylades morphs into the Hand of God halting Abraham, in a formal translation that amounts to a profound visual meditation, contained in one gesture, on the relationship between ritual murder in Greek myth and Biblical sacrifice.

The Orestes frieze provides not only the formal master-image but also the exegetical metanarrative behind the León tympanum. Like the hand of the nurse, God's commanding hand acts as the indictment of crime, but here it is no longer the impotent gesture of a servant unable to prevent the crime but the almighty Hand of God directly intervening in the course of events. On the tympanum, sacrifice is not condemned by reproach but stopped by interdiction. It is not framed morally by the emotional response of a fellow human, but legally by the unquestioned judgment of the Father. Yet the way in which, in the formal genealogy of the tympanum, the hand of the nurse exists within God's, introduces an unintentional level of exegesis to the Biblical episode - the realisation that deep inside God's ostensibly detached command lies a very human consideration for the consequences of the crime.

But if this act of artistic translation inspires a meditation on the human kernel of Biblical sacrifice such as I have just outlined, it also facilitates a meditation on the sacred dimension of murder in Greek tragedy. As Jean-Pierre Vernant observes, religious sacrifice in Greek tragedy seems to be an empty ritual performance, and it is in human murder, rather, where the sacred dimension of sacrifice is fully released:

The normal form of communication between gods and men is sacrifice, the invention of Prometheus. But, there are, precisely, no regular sacrifices in Aeschylus' tragic world: on the contrary, every sacrifice is 'corrupt'... Every attempt to sacrifice is brought to a halt ... Conversely, every murder, whether of a brother, a daughter, a spouse, or a father, is depicted as a sacrifice .... In Greek tragedy, the norm is 
presented only to be transgressed or because it has already been transgressed. It is in this respect that Greek tragedy derives from Dionysus, the god of confusion and transgression. ${ }^{55}$

The León artist, in transforming the scene of matricide from the sarcophagus into a sacred sacrifice in the tympanum, has revealed the sacred sacrificial nature contained, as Vernant says, in every murder in Greek tragedy, and clearly implied in Aeschylus's description of Clytemestra's execution.

It is difficult to find a more beautiful and complex artistic realisation of an 'iconology of the interval.' This cryptic phrase, introduced by Warburg in his 1929 journal, has been interpreted in reference to the montage structure of the Mnemosyne panels, which, as Philip-Alain Michaud points out, were meant to generate meaning through correlations between images:

This iconology is based not on the meaning of the figures - the foundation of interpretation for Warburg's disciples, beginning with Panofsky - but on the interrelationships between the figures in their complex, autonomous arrangement, which cannot be reduced to discourse. ${ }^{56}$

It is precisely in its understanding of the meanings generated by the intervals and correlations between the different figures, or Pathosformeln, of the Husillos sarcophagus, that the work of the León artist surpasses both that of his Jaca forerunners, and his late-Gothic (Pisanello) and Italian Renaissance counterparts. It is also by adopting an iconology of the interval as an analytical strategy that we can discover the profound reflection on sacrifice that emerges, only at the level of the visual, 'which cannot be reduced to discourse,' from a comparative analysis of the Orestes sarcophagus and the León tympanum. And, as generative kernel at the centre of it all we find the transcendental gesture of a hand that travels artistically the ontological distance between man and God, and stands as a brilliant materialisation of how Warburg, in Agamben's words, viewed gesture in the context of his project, 'as a crystal of historical memory.... which stiffened and turned into a destiny. ${ }^{.57}$

\section{Bend Sinister: Tragedy, History, and Historiography}

These three illustrious examples suggest that, parallel to Moralejo's stylistic genealogy, we can trace a second, iconographic, lineage emerging from the Husillos sarcophagus - one that centres on the themes of family crime and sacrifice. By following the Erinyes in their avenging wrath, we can witness myth

55 Vernant 1990, 263-264.

56 Michaud 2007, 251-52.

57 Agamben 2000, 53. 
bleeding over Christian iconography ... and over history. Indeed, the specific historical events, revolving around the question of dynastic genealogy, which inspired the commission of those monuments, especially San Martín de Frómista and San Isidoro de León, provide yet a third link connecting the Romanesque descendants of the Husillos sarcophagus.

The 'Orestes' and 'Electra' of this story are Alfonso VI, King of León-Castile (r. 1065-1109), and his older sister, the infanta Urraca. Their father, Fernando I (r. 1037-1065), divided his empire among his three sons, leaving Castile to the eldest, Sancho, León to Alfonso, and Galicia to García, the youngest. In the dynastic dispute that ensued among the brothers after Fernando's death in 1065, Urraca helped Alfonso overcome defeat, imprisonment and exile to be finally crowned king of the united realms of León, Castile and Galicia in 1072. To achieve this goal, she conspired in the murder of Sancho, and the life imprisonment of Garcia, who would spend the next 18 years, until his death in 1090, confined in a castle in the remote mountains of León. A true medieval Electra, Urraca was an unmarried princess dedicated to the dynastic heritage of her family, whose symbolic centre was the complex of San Isidoro de León, which she inherited through the institution of the infantazgo. ${ }^{58}$

When Garcia died, still in captivity, in 1090, Alfonso VI seemed to be at the height of his power and prestige, having achieved renown in the rest of Europe by conquering Toledo in 1085, and having crushed several rebellions and other internal dissensions, which were finally settled at the Council of Husillos in 1088. Poignantly, art again provided a silent commentary to history, for, around the time Alfonso and Urraca attended, with considerable amounts of hypocrisy, Garcia's royal exequies at San Isidoro de León, presided over, like the council of Husillos, by the papal legate Rainier (future pope Paschal II), the Orestes-Cain capital surely must have dazzled visitors to the recently built apse of San Martín de Frómista. The presence of this representation of Cain's crime, endowed with

58 The infantazgo was the portion of the royal patrimony comprising monastic foundations and was given to a princess on the condition that she remained unmarried, as a deo vota. Through this endowment, the infanta acted like a lay abbess exercising total dominion and economic control over the monastic estates of the realm, including the administration of justice (see Walker 1999). San Isidoro was the most important monastery of the kingdom, and the centre of a larger palatine complex integrated by the royal palace, the church, and a double monastery, dedicated to Saint Palagius (nuns) and San Isidoro (monks). In addition to keeping the relics of the most revered saint and cultural authority of the Visigothic age, which had been translated from Seville with great pomp by Fernando I in 1063 when the former church of St. John the Baptist was rebuilt and rededicated to San Isidore, the complex also housed the royal cemetery of the Kings of León. Due to this, the monastery was the symbolic heart of the memory of the Leonese dynasty, which regarded itself as the direct continuator of the lineage descending from the Visigothic monarchs that governed the peninsula in the 'Golden Age' before the Muslim invasion. For the historical context of San Isidoro, see Williams 1995. 
the patina of ancient tragedy, at the heart of Tierra de Campos - the area Alfonso had directly inherited from his father - could not offer a more suitable image for the original sin marking his ascent to power. It was only fitting that the monastery founded by the matriarch of the dynasty, Muniadomna, and entrusted to her stirpe, was sealed by the mark of Cain - a mark that run deep in their genealogical makeup.

As their Greek counterparts, therefore, Urraca and Alfonso were bound by fratricide, revenge and dynastic restoration. However, by the time of García's death, a sibling dissension had been slowly brewing between these 'Electra' and 'Orestes' who had triumphantly seized power in 1072 . Tinged with the complex psychological underpinnings of a Greek tragedy, the progressive distancing between Urraca (motherly sister/mentor/lover) and Alfonso VI would have immense artistic ramifications because it was fought, not in the battlefield with the sword, but, rather, in the infanta's seat of power, San Isidoro, with stone, tempera, and parchment. ${ }^{59}$

The direction of Alfonso's policies since the 1080's, which implied a progressive marginalisation of León and of San Isidoro, run counter to Urraca's profound alliance to the Leonese dynastic heritage and her role as the main benefactress of the institution. In the infanta's eyes, her brother seemed to be betraying the dynastic memory - with the creation of a new royal pantheon in the monastery of San Benito de Sahagun, which had become the centre of Cluniac reform in the kingdom -, and the prospective descendancy, with his insistence that his only son, Sancho Alfónsez, born of a Muslim concubine named Zaida, the widowed daughter-in-law of King al-Mutamid of Seville, be appointed as heir to the kingdom. It is within the context of this divergence of interests between Urraca and Alfonso in relation to the question of León that I propose to interpret the infanta's frantic patronage activity at San Isidoro at the end of the eleventh century, reflected mainly in the building of Royal Pantheon, with its famous frescos, and the construction of the new Romanesque basilica with the Portal of the Lamb.

It is in the iconographic programme of the Portal of the Lamb, with its central representation genealogical drama of Abraham, where the split between the two siblings, triggered by the urgency of the question of dynastic succession, can be more clearly detected. Here again the Orestes sarcophagus presents the mythological background that ripples through history because, if the figure of the older sister Electra appears as the instigator behind the dynastic tragedy carved on its main frieze, so is Urraca behind the genealogical drama carved on the tympanum of the Portal of the Lamb, where Abraham's choice between his

59 Rumours of the incestuous relationship between Urraca and Alfonso circulated early and were echoed by Islamic sources, see Menéndez Pidal and Lévi-Provençal 1948, and Cantarella 2007. 
legitimate heir Isaac and his discarded progeny Ishmael (regarded as progenitor of the Arabs in medieval chronicles) seems to address directly the dilemma that Alfonso had to face regarding the succession to his kingdom. Through the genealogical drama of the story of Abraham, the tympanum dramatises the position of a father who needed to make a series of difficult choices regarding his inheritance. At the time the tympanum was conceived Alfonso VI had to face a combination of Abraham's two most difficult choices. Sancho Alfónsez was the product of his union with a Muslim concubine (reminiscent of Ishmael) but he was also his firstborn son and chosen one (Isaac) - the one whom he would have to be willing to sacrifice in order to keep the covenant between God and his people. I believe it is from this context that the tympanum emerges, as an attempt to address the difficult situation of an impatient father wanting to recognise his only son as his legitimate heir and a Leonese party championed by his sister Urraca, who demanded from him the ultimate sacrifice that Abraham had to face and relinquish the position of his most beloved son, while they waited for his new marriage to yield an heir by a Christian mother.

Therefore Abraham's choice was really Alfonso's. It was the choice he had to make in the final years of his reign, it is the choice that was at stake when the Portal of the Lamb was built, and it is the final lesson given to Alfonso by his sister, the matriarchal gate-keeper of the Leonese dynastic line. By understanding the tympanum as a matriarchal work disguised within a patriarchal narrative, we can begin to visualise the spectral confrontation between Urraca, as the embodiment of the matriarchal tradition of the Leonese dynasty, and Alfonso VI that takes place there, in the guise of Sarah and Abraham. Comparative iconography reveals that the figure of Sarah is designed in clothing and disposition as a royal Leonese deo vota - an association which could not escape contemporary viewers. More strikingly, the head of Abraham, which represents a radical departure from the head types of all the other figures produced by this workshop, seems to consciously reflect the facial type afforded to the Kings of León in contemporary portraiture, and, in particular, to several portraits of Alfonso VI. ${ }^{60}$

60 In addressing these specific historical circumstances, the iconography of the Portal constitutes a larger statement asserting the birth of the rightful Christian prince as a divinely sanctioned occurrence, and the identity and mission of Christian kingship. The Zodiac functions in connection with the genealogical iconography of the tympanum and with the images of King David and St. Isidore, which are represented nearby, to form a statement defining the perfect Leonese monarch: genealogical purity (tympanum), moral character and destiny (Zodiac), and militant mission (emphasised by the anti-Muslim dimension of the iconography and by the Christian soldier which appears next to the figure of St. Isidore). See Prado-Vilar 2009, where taking the Aeneid as a methodological environment and ekphrasis as an analytical principle, I explore the imbrications between 
When the infanta Urraca died in 1101, with the Portal recently built, Alfonso moved steadily towards having Sancho Alfónsez accepted as his heir, finally confirming him officially in a Council held in León in $1107 .{ }^{61}$ It is another poignant piece of history that, soon after having been officially proclaimed heir to the Kingdom of León-Castile, Sancho Alfónsez, the son of the Muslim princess, was killed fighting the Murabit at the battle of Uclés (1108). ${ }^{62}$ 'Ishmael' had truly become 'Isaac' but, this time, there was no divine hand to stop the sacrifice, and Abraham/Alfonso had to give up his son in the service of God. Returning to León after the tragedy of Uclés, the king of LeónCastile could have observed how the imagery of the tympanum doubled as a specular representation of his own pain.

We have thus completed the outline of a hypothetical Mnemosyne panel that makes visible the trans-historical legacy of the Orestes sarcophagus in three genealogical movements: formal, iconographic, and historic. Yet a fourth tragic 'historiographic' genealogy inevitably emerges as a subtext for my present discussion, pointing towards a larger project which takes up where the work of M. Schapiro, S. Moralejo, and M. Camille left off. By outlining the genesis and formal vocabulary of an artistic tradition engaged in an incessant exploration of the semantic possibilities of the human body in direct dialogue with Roman art, Moralejo presented us with a unique case study to undertake a comprehensive analysis of the multivalent functions of the body in Romanesque sculpture, which not only accounts for the abstract and the social, as Schapiro had done, but also for the organic, the somatic and the tragic. In his perceptive review of Schapiro's essays on Romanesque art, entitled 'How New York stole the Idea of Romanesque Art,' Camille pointed out, more than a decade ago, the necessity to break with the textually oriented epistemology still dominating the field, and pursue the path of a sophisticated formalism. 'In my view,' wrote Camille, 'a far more innovative and powerful model for the art historian today are the essays Schapiro wrote in the thirties, where the body in all its materiality, conflicted desire and psychological subjectivity, rather than the text in its rationalisation through language, is the focus of exploring visual history. ${ }^{63}$ Even if here Camille credits Schapiro with doing something that, I believe, he never did, misreading his formalism as an interest in the body, the statement contains an insightful diagnosis of the state of the field and its possible future developments. To be sure, Schapiro's formalism, nurtured in the sensibility of the New York artistic avant-garde, was mostly concerned with the abstract and geometric aspects of

art, politics, and tragedy in the Kingdom of León-Castile during the reigns of Fernando I and Alfonso VI treating at length the themes outlined in this section.

61 See Reilly 1988, 326-344. According to Reilly, Alfonso VI finally married Zaida, who had been baptised as Isabel, in 1106 in order to legitimise their son.

62 See Reilly 1988, 345-363.

63 Camille 1994, 72. 
Romanesque sculpture, but did not pursue at all the body as an independent site of meaning. The explanatory drawings accompanying his famous essay on Souillac, unlike those illustrating Moralejo's (Figure 3.5), clearly show that, unlike the Spanish scholar, Schapiro was mainly interested in the shapes that the body describes in space and the relations they establish with the surrounding field, but not in the body as a somatic entity. ${ }^{64}$ It is not surprising, therefore, that when Schapiro turned his eyes to Spanish Romanesque sculpture, he found in the cloister of Silos a style more in tune with his own interests. Closely related to Moissac and Souillac - monuments that had already attracted Schapiro's attention - Silos represented within the stylistic trends of Spanish Romanesque sculpture a self-consciously conservative ensemble. In their adherence to strict geometrical patterns and linear figural design, the Silos artists largely sidestepped the experiments on plasticity and organic articulation that, as we have seen, were engaging the workshops of Languedoc and northern Spain, from Toulouse to Compostela at the turn of the twelfth century. Therefore, taking a cue from the title of Camille's essay on Shapiro, we could say that New York might indeed have been the place to steal a specific idea of Romanesque art and re-package it for the progressive intellectual circles of the mid-twentieth century, but not the place to undertake a full exploration of an important variant of the style tinged with classical models and deeply engaged with the somatic dimension of form. In Camille's wishful projection, however, there is an insightful prescription to rescue the study of Romanesque sculpture from the stagnation to which both the tyranny of the text and the abuse of the discourses of fantasy and marginality has brought it, signalling the way to a rediscovery of its tragic beauté oubliée.

\section{Bibliography}

Adhémar, J. Influences antiques dans l'art du Moyen àge français: recherches sur les sources et les thèmes d'inspiration (London, 1939).

Agamben, G. Means Without End. Notes on Politics (Minneapolis, 2000).

Baschet, J. Le sein du père. Abraham et la paternité dans l'occident médiéval (Paris, 2000).

64 Following his characterisation of Schapiro's Souillac essay as a prime example of his interest on the body, Camille states that 'Schapiro's iconographic argument ... is almost somatic in its constant play upon the body as the site of meaning, and his descriptive teeth never lose hold of the flesh of the forms, no matter how many layers of meaning are being sucked from them' (Camille 1994, 67). However, I would argue that, on the contrary, Schapiro's descriptive teeth never get hold of the flesh of the forms. His prose, purged of colouring and lyrical inflection, bared down to its basic logical relations, and tied up to a syntax that plays elegantly with symmetry and dissonance, echoes the geometrical network he strives to map for the reader (illustrated by the accompanying schemes). 
Bertaux, É. Sculpture chrétienne en Espagne dès origines au XIVe siècle, in: Histoire de l'art, vol. 2, pt. 1, edited by A. Michel (Paris, 1906), 244.

Bertaux, E. Recueil de Travaux dédié a la mémoire d'Émile Bertaux (Paris, 1924), 2-3.

Blázquez, J. M. Mosaicos romanos de España (Madrid, 1993).

Boder, P. Pray and Rubinstein, R. Renaissance Artists and Antique Sculpture: A Handbook of Sources (London, 1986).

Boswell, J. The Kindness of Strangers: The Abandonment of Children in Western Europe from Antiquity to the Renaissance (Hew Haven, 1988).

Braude, P. F. 'Cokkel in oure Clene Corn': Some Implications of Cain's Sacrifice. Gesta 7 (1968), 15-28.

Brendel, O. J. Borrowings from Ancient Art in Titian. Art Bulletin 37.2 (1955), $113-$ 125.

Cahn, W. and Seidel, L. Romanesque sculpture in American collections, vol. 1 (New York, 1979), $120-28$.

Camille, M. How New York Stole the Idea of Romanesque Art. Oxford Art Journal 17 (1994), 65-75.

Camille, M. Obscenity Under Erasure: Censorship in Medieval Illuminated Manuscripts, in: Obscenity: Social Control, and Artistic Creation in the European Middle Ages, edited by J. M. Ziolkowski (Leiden, 1998), 139-54.

Cantarella, T. Doña Urraca and Her Brother Alfonso VI: Incest as Politics. La Coronica. 35.2 (2007), 39-68.

Caviness, M. H. Retomando la Iconografía Vaginal. Quintana 6 (2007), 13-37.

Cazes, D. Sarcófago peleocristiano llamado 'de Saint-Clair', in: Exhibition. El Románico y el Mediterráneo: Cataluña, Toulouse y Pisa (1120-1180), edited by M. Castiñeiras, J. Camps, and I. Lorés (Barcelona, 2008), 330-331.

Crow, T. The Intelligence of Art (Chapel Hill, NC.: University of North Carolina Press, 1999), 79-103.

Didi-Huberman, G. Dialektik des Monstrums: Aby Warburg and the symptom paradigm. Art History 24.5 (2001), 621-645.

Didi-Huberman, G. L'image survivante: histoire de l'art et temps des fantômes selon Aby Warburg (Paris, 2002).

Durliat, M. La sculpture romane de la route de Saint-Jacques: de Conques à Compostelle (Mont-de-Marsan, 1990).

Falque Rey, E (ed.). Historia Compostellana, Corpus Christianorum. Continuatio Mediaevalis 70 (Turnhout, 1988).

Fernández-Guerra y Orbe, A. Sarcófago pagano en la Colegiata de Husillos, recién traído al Museo Arqueológico Nacional. Museo Español de Antigüedades I (Madrid, 1872), $11-48$.

Fita, F. Texto correcto del concilio de Husillos. Boletín de la Real Academia de la Historia 51 (1907), 410-413.

Fletcher, R. A. The Episcopate in the Kingdom of León in the Twelfth Century (Oxford, 1978).

Fletcher, R. A. Saint James's Catapult: The Life and Times of Diego Gelmirez of Santiago de Compostela (Oxford, 1984).

Frómista 1066-1904. San Martín, centenario de una resturación (Valladolid: Fundación del Patrimonio Histórico de Castilla y León, 2004).

Frontisi-Ducroix, F. The Invention of the Erinyes, in: Visualizing the Tragic: Drama, Myth and Ritual in Greek Art and Literature. Essays in Honour of Froma Zeitlin, edited by C. Kraus, S. Goldhill, H. P. Foley and J. Elsner (Oxford, 2007), 165176. 
Gaillard, G. Les débuts de la sculpture romane espagnole: Leon, Jaca, Compostelle (Paris, 1938).

García y Bellido, A. Esculturas romanas de España y Portugal vol. 1 (Madrid, 1949).

Gombrich, E. H. Aby Warburg: An Intellectual Biography, with a Memoir of the History of the Library by F. Saxl (London, 1970), 223.

Greenhalgh, M. The Survival of Roman Antiquities in the Middle Ages (London 1989).

Grivot, D. and Zarnecki, G. Gislebertus. Sculptor of Autun (New York, 1961), 68.

Gómez-Moreno, M. El arte románico español: Esquema de un libro (Madrid, 1934), 8489.

Hernando Garrido, J. L. Husillos, in: Enciclopedia del Románico en Castilla y León, Palencia, vol. 2 (Aguilar de Campoo, 2002), 1059-1069.

Hernando Garrido, J. L. El contexto de la restauración de San Martín de Frómista (1895-1904): El Edificio de la gran patria castellana y la propaganda católica, in: Frómista 1066-1904. San Martín, centenario de una resturación (Valladolid, 2004), $87-118$.

Hernando Garrido, J. L. Apostillas a la restauración de San Martín de Frómista (18951904): el contexto sociopolítico, in San Martín de Frómista, paradigma o historicismo? (Valladolid, 2005), 85-118.

Isidore of Seville. The Etymologies of Isidore of Seville, trans. S. A. Barney, W.J. Lewis, J.A. Beach, O. Berghof (Cambridge, 2006).

Kauffmann, C.M. Biblical Imagery in Medieval England 700-1550 (London, 2003).

Lacarra, M. Documentos para la Reconquista del Valle del Ebro, in: Estudios de la Edad Media de la Corona de Aragón, sección de Zaragoza, vol. 2 (Zaragoza, 1946), 473477.

Lyman, T. W. The Pilgrimage Roads Revisited. Gesta 8.2 (1969), 30-44.

McCann, A. M. Fragments on an Orestes Sarcophagus, in Roman Sarcophagi in the Metropolitan Museum of Art (New York, 1978), 53-60.

Menéndez Pidal, R, and E. Lévi-Provençal. Alfonso VI y su hermana la infanta Urraca. Al-Andalus 13 (1948), 157-66.

Michaud, Ph-A. Aby Warburg and the Image in Motion, translated by S. Hawkes (New York, 2007).

Montagu, J. Interpretations of Timanthes's Sacrifice of Iphigenia, in: Sight and Insight. Essays on Art and Culture in Honour of E. H. Gombrich at 85, edited by J. Onians (London, 1994), 305-325.

Moralejo, S. Sobre la formación del estilo escultórico de Frómista y Jaca, in: Actas del XXIII Congreso Internacional de Historia del Arte, Granada 1973, vol. 1 (Granada, 1976), $427-434$.

Moralejo, S. Pour l'interprétation iconographique du Portail de l'Agneau à Saint-Isidore de León: Les signes du zodiaque. Les cahiers de Saint-Michel de Cuixa 8 (1977), $137-173$.

Moralejo, S. La sculpture romane de la Cathédrale de Jaca: Etat des questions. Les cahiers de Saint-Michel de Cuxa 10 (1979), 79-106.

Moralejo, S. Les arts somptuaires hispaniques aux environs de 1100. Les cahiers de SaintMichel de Cuixa 13 (1982), 285-310.

Moralejo, S. La reutilización e influencia de los sarcófagos antiguos en la España medieval, in: B. Andreae and S. Settis (eds.), Colloquio sul reimpiego dei sarcofagi romani nel medievo. Pisa, 5-12 settembre 1982 (Marburg-an-der-Lahn, 1984), 187 $203=$ Moralejo $1984 \mathrm{a}$. 
Moralejo, S. Un reflejo de la escultura de Jaca en una moneda de Sancho Ramírez (+ 1094), in: Scritti di Storia dell'arte in onore di Roberto Salvini (Florence, 1984), 29 $35=$ Moralejo $1984 \mathrm{~b}$.

Moralejo, S. Artistas, patronos, y público en el arte del Camino de Santiago. Compostellanum 30 (1985), 395-430.

Moralejo, S. The Tomb of Alfonso Ansúrez (+1093): Its Place and the Role of Sahagún in the Beginnings of Spanish Romanesque Sculpture, in: Santiago, Saint-Denis, and Saint Peter. The Reception of the Roman Liturgy in León-Castile in 1080, edited by B. F. Reilly (New York, 1985), 63-100.

Moralejo, S. Modelo, copia y originalidad, en el marco de las relaciones artísticas hispano-francesas (siglos XI-XIII), in: Ve Congrès Espanyol d'Història de l'art. Barcelona, 29 d'octubre al 3 de novembre de 1984, vol. 1 (Barcelona, 1987), 89-115.

Moralejo, S. Cluny y los orígenes del románico palentino: El contexto de San Martín de Frómista, in Jornadas sobre el arte de las órdenes religiosas (Palencia, 1990), 23.

Moralejo, S. On the Road: The Camino de Santiago, in: Exhibition. The Art of Medieval Spain, A.D. 500-1200. (New York, 1994), 175-183.

Moralejo, S. Two Capitals, in: Exhibition. The Art of Medieval Spain, A.D. 500-1200 (New York, 1994), 211.

Morales, Ambrosio de. Viage de Ambrosio de Morales por orden del rey D. Phelipe II. A los Reynos de Leon, y Galicia, y Principado de Asturias (Madrid, 1977).

Neils, J. The Orestes Sarcophagus and Other Classical Marbles. The Bulletin of the Cleveland Museum of Art 71 (1984), 103-115.

Nora, P. Between Memory and History: Les Lieux de Mémoire. Representations 26 (1989), 7-24.

Patton, P. Cain's Blade and the Question of Midrashic Influence in Medieval Art, in: Church, State, Vellum and Stone. Essays on Medieval Spain in Honor of John Williams, edited by T. Martin and J. A. Harris (Leiden, 2005), 413-441.

Prado-Vilar, F. Saevum facinus: estilo, genealogía y sacrificio en el arte románico español. Goya 324 (2008), 173-199.

Prado-Vilar, F. Lacrimae rerum: San Isidoro de León y la memoria del padre. Goya 328 (2009), 195-221.

Reilly, B. F. The Kingdom of León-Castilla under Queen Urraca (Princeton, 1982).

Reilly, B. F. The Kingdom of León-Castilla under King Alfonso VI, 1065-1109 (Princeton, 1988).

Rose, L. The Survival of Images: Art Historians, Psychoanalysts, and the Ancients (Detroit, 2001).

Scheller, R. W. Exemplum. Model-Book Drawings and the Practice of Artistic Transmission in the Middle Ages (ca. 900 - ca. 1470) (Amsterdam, 1995).

Serrano Fatigati, E. Esculturas de los siglos IX al XIII astures, leonesas, castellanas y gallegas. Boletín de la Sociedad Española de Excursiones 9 (1901), 35-45.

Siedel, L. Legends in Limestone. Lazarus, Gislebertus, and the Cathedral of Autun (Chicago, 1999).

Schade, S. Charcot and the Spectacle of the Hysterical Body: The 'pathos formula' as an aesthetic staging of psychiatric discourse - a blind spot in the reception of Warburg. Art History 18.4 (1995), 499-517.

Schapiro, M. Cain's Jawbone That Did The First Murder, in: Late Antique, Early Christian and Medieval Art. Selected Papers (New York, 1979), 249-265.

Schapiro, M. The Angel with the Ram in Abraham's Sacrifice: A Parallel in Western and Islamic Art, in: Late Antique, Early Christian and Medieval Art (New York, 1979), $289-318$. 
Toynbee, J. M. C. The Hadrianic School: A Chapter in the History of Greek Art (Cambridge, 1934), 166-177.

Vernant, J.-P. Aeschylus, the Past and the Present, in: Myth and Tragedy in Ancient Greece (New York, 1990), 249-272.

Walker, R. Sancha Urraca and Elvira: the virtues and vices of Spanish royal women 'dedicated to God'. Reading Medieval Studies, XXIV (1998), 113-138.

Warburg, A. Dürer and Italian Antiquity, in: The Renewal of Pagan Antiquity: Contributions to the Cultural History of the European Renaissance, edited by K. W. Forster (Los Angeles, 1999), 553-558.

Werckmeister, O. K. Pain and Death in the Beatus of Saint Sever. Studi Medievali 14 (1973), 565-626.

Williams, J. J. A Source for the Capital of the Offering of Abraham in the Pantheón of the Kings in León, in: Scritti di Storia dell'arte in onore di Roberto Salvini (Florence, 1984), 25-28.

Williams, J. J. Leon: The Iconography of the Capital, in: Cultures of Power: Lordship, Status, and Process in Twelfth-Century Europe, edited by T. N. Bisson (Philadelphia, 1995), $231-258$.

Zanker, P. and B. Ewald. Mit Mythen Leben: Die Bilderwelt der römischen Sarkophage (Munich, 2004). 